\title{
COMPETÊNCIAS DOCENTES: UM ESTUDO COM PROFESSORES DE GRADUAÇÃO EM CIÊNCIAS CONTÁBEIS NO RIO GRANDE DO SUL
}

\author{
Giovana Bolzan' \\ Maria Ivanice Vendruscolo²
}

- Artigo recebido em: 19/03/2021 -- Artigo aceito em: 14/06/2021 -.' Segunda versão aceita em: 14/07/2021

\section{RESUMO}

Utilizando como embasamento teórico a Matriz de Competências Docentes (Vendruscolo, 2015), a pesquisa objetiva analisar o grau de esforço e a frequência de mobilização das competências docentes pelos professores de graduação em Ciências Contábeis no Rio Grande do Sul (RS). Trata-se de um estudo descritivo, quantitativo e de levantamento - por meio de questionário online. Os dados foram analisados por estatística descritiva e por análise fatorial. A amostra é composta por 243 professores e/ou coordenadores de cursos de graduação presencial no RS que lecionam disciplinas do eixo de formação profissional do currículo de Ciências Contábeis. Os resultados apontam haver dificuldades dos professores para operacionalizar as competências docentes e para aplicar conhecimentos de tecnologia da informação e das teorias de ensino e aprendizagem. O artigo contribui para a busca de melhorias no processo de ałuação e de profissionalização dos docentes de Ensino Superior em Ciências Contábeis. Por meio de dados empíricos, auxilia a academia e a sociedade a identificar obstáculos às práticas docentes e a propor soluções para tais dificuldades.

Palavras-Chave: Ensino. Ciências Contábeis. Competências Docentes. Professor de Contabilidade.

\footnotetext{
1 Mestre em Controladoria e Contabilidade pela Universidade Federal do Rio Grande do Sul UFRGS. Endereço: Universidade Federal do Rio Grande do Sul, Faculdade de Ciências Econômicas, Departamento de Ciências Contábeis e Atuárias. Endereço: Av. João Pessoa, 52 - Sala 1 1, Porto Alegre, RS, Brasil. E-mail: bolzangiovana@gmail.com. https://orcid.org/0000-0002-7363-1183
}

2 Doutora em Informática na Educação pela Universidade Federal do Rio Grande do Sul UFRGS. Endereço: Universidade Federal do Rio Grande do Sul, Faculdade de Ciências Econômicas, Departamento de Ciências Contábeis e Atuárias. Endereço: Av. João Pessoa, 52 - Sala 11, Porto Alegre, RS, Brasil. Telefone: (51) 3308-3487. E-mail: maria.ivanice@ufrgs.br. https://orcid.org/0000-0002-2132-5029

Editora responsável pela aprovação do artigo: $\mathrm{Dr}^{\mathrm{a}}$. Bruna Camargos Avelino Editora responsável pela edição do artigo: Dra ${ }^{a}$. Bruna Camargos Avelino 


\title{
TEACHING SKILLS: A STUDY WITH ACCOUNTING TEACHERS IN RIO GRANDE DO SUL (BRAZIL)
}

\begin{abstract}
Using as a theoretical basis the Matrix of Teaching Competences (Vendruscolo, 2015), this research aimed to analyze how professor at the undergraduate level apply teaching skills in Accounting Sciences in Rio Grande do Sul (RS), state of Brazil. This is a descriptive, quantitative survey study. Data was collected using an online questionnaire and was analyzed by means of descriptive statistics and factor analysis. The sample is composed of 243 professors and / or coordinators of on-campus undergraduate courses in RS, who teach disciplines in the professional education axis of the Accounting Sciences program. The results show professor display difficulties in applying teaching methodologies - such as teaching and learning theories - and in employing their knowledge on information technology. By means of empirical data, this article provides insights about the obstacles to the accounting teaching practice and how to overcome them.
\end{abstract}

Keywords: Teaching. Accounting Sciences. Teaching Skills. Teaching Competences. Accounting professor.

\section{INTRODUÇÃO}

A conjuntura do Ensino Superior é marcada por crescentes e rápidas transformações nos contextos educacional, acadêmico, social e cognitivo. $O$ desenvolvimento científico e o tecnológico são, em parte, responsáveis por mudanças na maneira como os professores prepararam seus alunos para o mercado de trabalho. À exceção dos docentes provenientes das licenciaturas, muitos professores do ensino superior não contaram com uma formação sistemática necessária para a construção de uma identidade profissional para a docência e as desenvolveram na prática (Slomski, 2007; Libâneo, 2008). Percebese a necessidade de uma formação docente mais adequada como instrumento para a busca por uma educação de qualidade (Libâneo, 2008). Conforme destaca Laffin (2005), tal situação também é identificada na área contábil, na qual o processo de transição de discente a docente se concretiza sem uma efetiva preparação ao exercício da docência contábil.

Para se desenvolver de forma que contemple satisfatoriamente os anseios da sociedade, o docente necessita compreender que a prática educativa se realiza a partir dos diversos elementos que circundam sua vida (Libâneo, 2008; Miranda, 2010). De acordo com Vendruscolo (2015), a atuação docente ocorre em diferentes contextos: (1) educacional, relativo ao processo de ensinoaprendizagem; (2) acadêmico, domínio dos conteúdos disciplinares específicos associados ao entendimento de aspectos teóricos que cercam o assunto em determinada área; (3) cognitivo, com as condições de analisar situações, complexas ou não, de refletir, de promover a autorreflexão, de aprender de forma contínua; (4) social, relacionar-se com os alunos, comunicar-se adequadamente, transformar ideias e conhecimento em mensagens de ensino claras, envolver os alunos e trabalhar em equipe.

Dada essa complexidade e, considerando que os docentes das Ciências Contábeis não estão pedagogicamente preparados para o exercício da 
docência (Nossa, 1999; Swain \& Stout, 2000; Farias \& Araujo, 2016; Miranda, Carrazana, Pereira, Araujo, \& Silva, 2017; Hillen, Laffin, \& Ensslin, 2018; Lima \& Araujo, 2019), além de que, no lapso dos últimos 20 anos, subsistem diversos problemas relacionados ao desenvolvimento de competências docentes, ganham força questionamentos a respeito de aspectos qualitativos da formação pedagógica stricto sensu em Contabilidade. Da mesma forma que em qualquer outro nível de ensino, em Ciências Contábeis também é desejável que os professores desenvolvam competências docentes em geral e construam conhecimentos específicos das disciplinas que ministram (Vasconcelos, 2009; Slomski, Megliorini, Lames, 2013; Vendruscolo, 2017; Alves \& D'Souza, 2018; Hillen et al., 2018; Araújo, Leal, Lourenço, 2021). Por sua vez, Bolzan, Vendruscolo, Sallaberry e Diehl (2020) apontam os desafios a serem superados no âmbito da educação contábil, especialmente aqueles relacionados à qualificação do corpo docente, dos discentes e da estrutura curricular.

Estudos demostram que os programas stricto sensu de formação de professores na área contábil nem sempre estão adequados à formação do professorado, uma vez que são voltados prioritariamente à formação de pesquisadores (Slomski, 2007; Slomski \& Martins, 2008; Andere \& Araújo, 2008; Miranda, 2010; Lapini, 2012; Masetto, 2012; Slomski, Lames, Megliorini, \& Lames, 2013; Nganga, Botinha, Miranda, \& Leal, 2016; Miranda et al., 2017; Lima \& Araújo, 2019; Farias, Stanzani, Lima, \& Araújo, 2020) e que a formação pedagógica e o desenvolvimento de competências didático-pedagógicas são negligenciados em sua formação, restando aos professores desenvolvê-las por meio de esforços individuais em sua prática de sala de aula (Swain \& Stout, 2000; Laffin, 2005 ; Marshall, Dombrowski, Garner, Smith, 2010; Lapini, 2012; Slomski et al., 2013; Engel, Vendruscolo, \& Bianchi, 2015; Miranda et al., 2017; Silva \& Bruni, 2017; Hillen et al., 2018; Farias et al., 2020; Slomski, Anastácio, Araújo, Slomski, \& Carvalho, 2020; Araújo, Leal, \& Lourenço, 2021).

Neste contexto, problemas didático-pedagógicos são enfrentados pelos docentes de Contabilidade no Brasil ao longo da sua carreira (Araujo \& Mello, 2014; Araújo, Lima, Oliveira, \& Miranda, 2015; Nganga et al., 2016; Araújo et al., 2021) demonstrando necessidade de uma formação pedagógica formal e continuada consistente (Libâneo, 2008). A formação pedagógica em programas de pós-graduação vem sendo continuamente recomendada por estudos que tratam da docência em Ciências Contábeis no Brasil (Nossa, 1999; Giorgi, Pizolato, \& Moretiin, 2001; Laffin, 2005; Andere \& Araújo, 2008; Farias \& Araújo, 2016; Araújo, 2017; Farias \& Araújo, 2018; Hillen et al., 2018). Estudos internacionais também destacam essa fragilidade na formação dos docentes em Ciências Contábeis: Swain e Stout (2000), Marshall, et al. (2010) e Del Mundo e Refozar (2013). Dentre estes, alguns autores investigam, especificamente, o tema competências docentes, dentre os quais se destacam: Nossa (1999), Swain e Stout (2000), Giorgi, Pizolato e Morettin (2001), Vasconcelos (2009), Marshall et al. (2010), Del Mundo e Refozar (2013), Slomski et al. (2013), Vendruscolo $(2015,2017)$, Zanella, Antonelli e Bortoluzzi (2017), Alves e D'Souza (2018), Farias et al. (2020) e Araújo, Leal e Lourenço (2021). Cada vez mais, a mobilização das competências docentes tem assumido posição de destaque quando a investigação diz respeito à educação superior. 
Assim, a fim de contribuir com dados empíricos para esta discussão, a questão que motiva esta pesquisa é: qual o grau de esforço e a frequência de mobilização das competências docentes pelos professores de graduação em Ciências Contábeis no Rio Grande do Sule Por objetivo, analisar o grau de esforço e a frequência de mobilização das competências docentes pelos professores de graduação em Ciências Contábeis no Rio Grande do Sul por meio de levantamento junto a sujeitos representativos da população e análise fatorial dos dados.

A escolha de docentes do Rio Grande do Sul pautou-se na ausência de estudos anteriores que tenham caracterizado a população docente da região, bem como de análises em relação à mobilização das suas competências docentes. Além disso, a limitação da pesquisa ao âmbito do estado do RS deuse em função da falta de acessibilidade a um cadastro nacional de docentes as buscas de nomes e de e-mails foram feitas manualmente nos sites das Instituições de Ensino Superior (IES) e em artigos publicados pelos docentes, o que impossibilitou a expansão da pesquisa para todo o país. No que tange às competências selecionadas para análise, optou-se por investigar quatro dentre as consideradas mais desenvolvidas e duas dentre as menos desenvolvidas segundo o estudo de Vendruscolo (2015).

Considerando que a docência requer formação profissional para seu exercício (Libâneo, 2008), compreender como os professores de Contabilidade vêm mobilizando suas competências docentes contribui com dados empíricos pela percepção dos professores e teóricos para 0 debate e para 0 aprofundamento de estudos em programas de pós-graduação nesta temática que resultem em melhorias efetivas na formação docente. Conforme já apontado, o docente da área contábil passa por um processo de formação em programas stricto sensu voltados prioritariamente à pesquisa (Nganga et al., 2016) - essa formação carece de desenvolvimento de determinadas competências docentes, as quais são necessárias à sua atuação na prática de sala de aula. É esperado que os docentes se deparem com dúvidas, inquietações e questionamentos que passam a exigir soluções em relação às suas práticas pedagógicas. Ainda que a análise das demais perspectivas pudesse gerar informações relevantes, estudar a as competências docentes do professor, a partir da sua própria percepção, permite levá-lo à reflexão sobre seu fazer pedagógico, podendo auxiliar no seu processo formativo, contribuir para a produção de mudanças nas suas práticas e, consequentemente, influenciar na melhoria da qualidade do ensino.

Nesse âmbito, o estudo contribui com a discussão acadêmica sobre a temática ao ressaltar a necessidade das Instituições de Ensino Superior (IES) resgatarem o papel do professor, repensarem sua formação, construírem espaços para os docentes refletirem sobre sua atuação pedagógica e de se preocuparem com a qualidade do corpo docente. De forma pragmática, também contribui com os estudantes de Ciências Contábeis ao evidenciar o esforço dos seus docentes em desenvolverem suas competências e ao ressaltar a relevância da interação entre tais agentes no processo de ensino e aprendizagem. Além disso, contribui para que os órgãos de classe da área contábil, possam fornecer subsídios para a implementação de programas de educação continuada capazes de contemplar as necessidades pedagógicas dos professores dos cursos de graduação em Contabilidade de forma sistemática. Os dados empíricos do estudo agregam conteúdo informacional relevante para os programas stricto sensu da 
área contábil, no intuito de auxiliá-los a revisar seus currículos no tocante a aspectos da formação docente, bem como contemplar linhas de pesquisas específicas para a Educação em Contabilidade.

Em suma, as contribuições deste estudo apresentam atributos teóricos e práticos para responderem anseios da sociedade e do mercado profissional, estimulando, assim, a busca de melhorias contínuas para o ensino superior brasileiro, em geral, e, de forma específica, para a área contábil. O estudo delimita-se à análise da percepção dos docentes quanto aos aspectos de esforço percebido e a frequência de mobilização das competências docentes e não aos aspectos cognitivos e subjetivos ocorridos no processo de desenvolvimento de competências docentes, o que demandaria observação participante e a adoção de teorias de construção de conhecimento como fundamentação teórica.

\section{REFERENCIAL TEÓRICO}

\subsection{Competências para Docência em Contabilidade}

Dado que a docência requer formação profissional para seu exercício (Libâneo, 2008) e o desenvolvimento de competências específicas, alguns autores da Contabilidade buscam identificar competências docentes, dentre os quais se destacam: Nossa (1999), Swain e Stout (2000), Giorgi, Pizolato e Morettin (2001), Vasconcelos (2009), Marshall et al. (2010), Del Mundo e Refozar (2013), Slomski et al. (2013), Vendruscolo (2015, 2017), Zanella et al. (2017), Alves e D'Souza (2018), Farias et al. (2020) e Araújo et al. (2021).

Conforme Vendruscolo (2015, p. 52), "as competências docentes representam o conjunto de competências (conhecimentos, habilidades e atitudes) relacionadas entre si que o professor mobiliza e articula para obtenção dos objetivos educacionais e para a resolução das situações oriundas no processo de ensino e aprendizagem". Por sua vez, a autora mapeou e validou uma matriz de competências docentes em seus elementos: conhecimentos, habilidades e atitudes para cursos de graduação em Ciências Contábeis no Brasil relacionados à concordância, à importância, à relevância e ao nível de desenvolvimento. A Matriz de Competências Docentes em Contabilidade, resultante da pesquisa, é formada por um conjunto de dezoito competências das classes Educacional, Cognitiva, Social e Acadêmica, que engloba a amplitude das atividades de ensino, pesquisa e extensão, inerentes à natureza do exercício da docência superior (Vendruscolo, 2017). A autora identificou que as competências mais desenvolvidas são: técnica, comunicação, didática, autonomia e reflexão - as três primeiras também julgadas como as competências mais importantes na opinião dos 398 docentes participantes no Brasil. O estudo revelou, ainda, que dentre as competências parcialmente ou pouco desenvolvidas estão as competências pedagógica, tecnológica e política. A análise da presente pesquisa pautou-se, sob os contextos acadêmico, educacional, social e cognitivo, nas seguintes competências: técnica, comunicação, didática, de reflexão (quatro das mais desenvolvidas), pedagógica e tecnológica (duas das menos desenvolvidas). 
A competência técnica está relacionada ao domínio do conteúdo, ao conhecimento de formas eficazes de desenvolvê-lo com os alunos (Pereira, 2007; Miranda, 2010), à aplicação prática do conhecimento, a qual está intimamente ligada ao contexto de ação do professor e ao seu modo de exercer a docência (Tardif \& Raymond, 2000). Em virtude da internacionalização das práticas contábeis, o docente que não esteja em constante atualização terá dificuldades para propor atividades de ensino que preparem, de fato, os futuros profissionais (Vasconcelos, 2009). Essa busca pela atualização envolve a formação continuada do docente, que, para Laffin (2005), não deve ficar restrita aos cursos de atualização, sendo responsabilidade tanto da instituição quanto do próprio professor realizá-la.

O desenvolvimento da competência de comunicação é um aspecto importante no dia a dia do professor, pois o processo de ensino depende, fundamentalmente, de uma comunicação eficaz, de modo que falhas nesse processo tendem a refletir em dificuldades por parte do aluno na assimilação dos assuntos abordados pelo professor (Vasconcelos, 2009). Essa é uma das competências mais bem avaliadas pelos alunos como relevantes a um bom professor (Vasconcelos, 2009; Miranda, Casa Nova, \& Cornacchione Jr., 2012). 0 docente deve ser capaz de ouvir, processar e compreender a mensagem, expressar-se com clareza, utilizar terminologias adequadas, tom de voz, deve argumentar com coerência e propriedade, relacionar-se bem com os colegas, utilizar o feedback de forma adequada, facilitar a interação entre as partes envolvidas, entre outras (Libâneo, 2008; Vasconcelos, 2009; Farias, 2016).

Questões relacionadas às competências didática e pedagógica dos professores têm sido objeto de constantes preocupações na literatura contábil. Estudos mostram que a preparação pedagógica dos docentes de Contabilidade está muito aquém do necessário (Nossa, 1999; Laffin, 2005; Andere \& Araújo, 2008; Marshall et al. 2010; Miranda et al. 2012; Vendruscolo \& Behar, 2014). Na presente pesquisa, essas competências são tratadas em conjunto, pois estão intrinsecamente relacionadas no âmbito do contexto acadêmico; o desenvolvimento de uma pressupõe o incremento da outra para o adequado exercício da docência.

A prática pedagógica é um espaço de construção dos saberes profissionais (Slomski \& Martins, 2008) articulada a partir das experiências de ensino, dos saberes da pedagogia, da didática e do processo de troca coletiva de experiências e práticas, permitindo aos professores o desenvolvimento da consciência crítica e reflexiva e a aprendizagem profissional (Miranda, Santos, Casa Nova, \& Cornacchione, 2013). Em função disso, Vendruscolo (2015) mapeou as competências didáticas e pedagógicas dos docentes de Ciências Contábeis elencando em relação às didáticas, as competências de: conhecimento didático do conteúdo, produção de materiais, apresentação dos conteúdos, condução de discussões, objetividade, teorização das práticas, mediação pedagógica e tutoria, desafiar os alunos, construção de práticas docentes, dar suporte em tarefas cognitivas de esclarecimento de dúvidas e fornecer feedback; e, em relação às pedagógicas, as competências: conhecimento do processo de ensino e aprendizagem e de etapas de desenvolvimento da aprendizagem, de estilos de aprendizagem, de como se dá o conhecimento em cada etapa de desenvolvimento e a compreensão do processo, de concepção pedagógica da atividade de ensino, de adequar seu fazer pedagógico. Essas 
competências são, segundo Vasconcelos (2009), absolutamente necessárias para um docente, pois são capazes de melhorar seu desempenho na construção do conhecimento. É a partir do desenvolvimento desta competência que surge um comprometimento maior com as questões da sala de aula; ela representa o diferencial de qualidade do professor, preparando-o para as mudanças sociais.

O professor tem relevância na produção e estruturação do conhecimento pedagógico, razão pela qual, o docente deve ter um papel ativo e reflexivo na educação e não um papel meramente técnico, reduzido à execução de normas, receitas ou à aplicação de teorias exteriores. Para Slomski e Martins (2008, p. 6) "O modelo reflexivo é fundamental na formação de professores, especialmente na área Contábil, pois visa ao desenvolvimento de atitudes e competências problematizadoras das práticas de ensino e ao alcance da autonomia pessoal e profissional do corpo docente". A atividade pautada na racionalidade reflexiva zela pela existência de um professor que examina frequentemente os resultados de suas ações, atento às mudanças que ocorrem, preocupado com a aprendizagem do aluno, que faz da sua prática um espaço para refletir e melhorar o processo de ensino-aprendizagem (Frauches, 2015).

Competências para lidar com as novas tecnologias têm sido cada vez mais exigidas em razão da crescente modernização dos meios de comunicação. O atual docente dispõe de outro ambiente de aprendizagem, próprio da era tecnológica: o ambiente virtual de aprendizagem (Masetto, 2012). As tecnologias da informação permitiram multiplicar os ambientes e as estratégias de aprendizagem para muito além da sala de aula e vêm sendo largamente utilizadas no âmbito da educação como ferramentas de apoio às atividades docentes, pois elas são capazes de conferir um papel mais ativo à Educação favorecendo a interação e a interatividade, a colaboração e a cooperação (Costa, Duqueviz, \& Pedroza, 2015). Isso leva à necessidade de repensar constantemente o que precisa ser aperfeiçoado tanto nas pessoas quanto nas organizações para que se adequem às novas tendências da realidade atual (Vasconcelos, Cavalcante, \& Monte, 2012).

\subsection{Trabalhos Correlatos}

Estudos nacionais e internacionais vêm investigando a formação docente sob diferentes aspectos: Andere e Araújo (2008), Frauches (2015), Araújo et al. (2015), Lima et al. (2015), Vendruscolo e Behar (2014), Vendruscolo (2015), Perazo, Machado, Cruz e Quintana (2016) e Farias et al. (2020).

Andere e Araújo (2008) analisaram a formação do professor de Contabilidade e identificaram que, em primeiro lugar, os programas são voltados à formação de pesquisadores com conhecimentos teóricos e específicos da área contábil e, em segundo lugar, à formação pedagógica incentivando a docência e o desenvolvimento de habilidades didático-pedagógicas. Marshall et al. (2010) realizaram pesquisa sobre 0 ensino da Contabilidade com professores americanos e constataram que, quando se pretende se tornar um professor de Contabilidade eficaz, não haveria qualificação capaz de substituir a experiência no ensino e na prática contábil. 
Frauches (2015) delineou o perfil dos saberes que fundamentam a prática pedagógica de docentes que atuam em um curso de Ciências Contábeis e verificou que, construído na ação dos docentes, o saber prático, pode ser caracterizado como existencial, social e pragmático, permeado por crenças, valores e princípios éticos que decorrem das suas trajetórias e vivencias, na profissão contábil, na docência e, especialmente, no contexto em que atuam.

Os estudos de Araújo et al. (2015) e de Lima et al. (2015) mapearam os principais problemas enfrentados pelos docentes de Contabilidade no Brasil no ingresso, na carreira e nas fases posteriores e os problemas enfrentados pelos professores no exercício de suas funções demonstrando a necessidade de uma formação pedagógica dos docentes de Contabilidade capaz de habilitá-los a lidar com a diversidade discente e com as ferramentas necessárias para motivar os estudantes.

Nessa perspectiva, Perazo et al. (2016) avaliaram o perfil dos docentes dos cursos de Ciências Contábeis de três instituições públicas de Ensino Superior no RS, em termos de qualificação acadêmica, pedagógica e profissional e constataram que um reduzido número de docentes realizou algum curso complementar da área pedagógica ao longo da carreira, o que sinaliza a necessidade de investir em qualificações acessórias, sobretudo nos âmbitos acadêmico e pedagógico.

Vendruscolo (2015) elaborou a Matriz de Competências Docentes em Contabilidade, a qual contempla 18 competências que revelam as atividades dos docentes nas instâncias acadêmicas de ensino, pesquisa e extensão e as atividades administrativas e burocráticas do trabalho cotidiano do docente, agrupadas em quatro classes: i) Educacional: envolvendo as competências relacionadas ao processo de ensino e aprendizagem - Curricular, Pedagógica, Metodológica, Tecnológica, Didática e Avaliativa; ii) Cognitiva: diz respeito às atividades intelectuais do professor, abrangendo as competências Planejamento, Organização, Reflexão, Análise, Gestão e Autonomia; iii) Social: englobando as competências Comunicação, Trabalho em Equipe, Afetiva e Política; iv) Acadêmica: relativa à área de conhecimento específico e de conhecimento científico, composta pelas competências Técnica e Pesquisa.

Farias et al. (2020) analisaram como os professores titulados em contabilidade percebem os possíveis espaços formativos para a profissão docente. Os resultados da pesquisa revelaram que a autoformação é o espaço formativo que mais contribui para o desenvolvimento de competências para a docência. Os autores agruparam as competências analisadas em três fatores como espaços formativos para a docência, quais sejam: Programas de PósGraduação, Instituição de Ensino Superior enquanto espaço laboral e Autoformação.

Conforme verificado nos estudos apresentados, a formação dos docentes é voltada para a aquisição de conhecimentos teóricos e específicos da área contábil, enquanto a formação didático-pedagógica seria relegada a segundo plano, quando deveria ser priorizada (Nganga et al. 2016). Os estudos apontam, ainda, a relevância dos esforços individuais para desenvolvimento das competências docentes e a necessidade de maior comprometimento com a educação continuada dos docentes, especialmente em relação à formação pedagógica. Neste contexto, a presente pesquisa se diferencia e complementa 
as demais ao analisar a mobilização de competências docentes sob a percepção de professores de graduação em Ciências Contábeis no RS.

\section{PROCEDIMENTOS METODOLÓGICOS}

No quesito abordagem do problema, o estudo é classificado como quantitativo; quanto ao objetivo, a pesquisa é descritiva (Colauto \& Beuren, 2018). O procedimento técnico utilizado foi o de levantamento por meio de questionário, valendo-se de um corte transversal.

A população é composta pelos professores dos cursos presenciais de graduação em Ciências Contábeis em funcionamento no estado do Rio Grande do Sul (RS). O levantamento das IES foi realizado no sítio do e-Mec em 01 de março de 2017, identificando 117 cursos, dos quais 92 são ministrados em modalidade presencial em 67 distintas IES. A identificação dos sujeitos na população possibilitou a elaboração de uma base de dados que contemplou nome, universidade e e-mail de 643 docentes. Contudo, não foi possível conhecer o número de professores existentes na região pesquisada, uma vez que não há um cadastro dos docentes acessível ao público, o que impossibilitou o cálculo da probabilidade de cada indivíduo ser selecionado na amostra (Colauto \& Beuren, 2018). A amostragem se efetivou por acessibilidade e pode ser classificada como não probabilística. Os critérios para seleção da amostra, incluídos no instrumento de coleta, foram: i) ser professor e/ou coordenador de curso presencial de graduação em Ciências Contábeis, no estado do Rio Grande do Sul, no momento da coleta dos dados; ii) lecionar disciplinas do eixo de formação profissional do currículo de Contabilidade.

Os dados foram coletados por meio de questionário, o qual contemplou dois blocos de questões: i) dados para a caracterização dos respondentes: gênero, faixa etária, tempo de carreira docente, região de atuação, carga horária de trabalho, número médio de alunos por turma, IES de atuação, número médio de disciplinas ministradas por semestre na modalidade presencial e na modalidade a distância, preparação para o exercício da docência, postura da IES em relação a atividades para a docência, formação acadêmica, formação para a docência e desenvolvimento de competências pedagógicas; ii) dados para identificação do grau de esforço percebido pelos professores e das frequências para operacionalizar as competências docentes. Cada bloco de questões do questionário foi elaborado tendo em vista os objetivos da pesquisa e a fundamentação teórica.

As questões relativas ao esforço e à frequência foram apresentadas na escala Likert de 5 (cinco) pontos, a qual oferece a possibilidade de medição da intensidade da opinião do respondente nos questionamentos (Likert, 1975). A escala utilizada, em relação à percepção do esforço foi (1) muito difícil, (2) difícil, (3) nem fácil, nem difícil, (4) fácil, (5) muito fácil; e, em relação à frequência, foi (1) nunca, (2) raramente, (3) algumas vezes, (4) muitas vezes e (5) sempre. O préteste do instrumento de coleta foi realizado em julho de 2017 junto a seis docentes representativos do grupo de indivíduos a ser estudado. A versão final do questionário foi disponibilizada na plataforma eletrônica Google Forms, de maneira que pudesse ser acessada por meio do link disponibilizado no convite 
para participação da pesquisa. Foram efetuados três envios do questionário no período de 31 de julho de 2017 a 18 de setembro de 2017. Ao final, foram obtidas 243 respostas válidas.

A análise foi realizada em quatro etapas. Primeiramente (etapa 1), os componentes da pesquisa foram analisados e avaliados por meio de estatística descritiva (Gujarati, 2006). Essa análise apresentou distribuições de frequência, medidas de posição (média aritmética, mediana e moda), medidas de dispersão (amplitude total e desvio padrão), comparação de frequências (percentagem e taxas). Procedeu-se o Teste Qui-quadrado de Pearson para verificar se haveria associação entre as variáveis relacionadas às atitudes e o tipo de IES (Hair, Black, Babin, Anderson, \& Tatham, 2019). Na sequência (etapa 2), foi analisada a percepção dos respondentes a respeito do grau de dificuldade ou facilidade com que determinadas habilidades e atitudes são exteriorizadas por meio de 22 questões avaliadas com escala Likert de cinco pontos. Para determinação do grau de esforço, considerou-se: alto ("muito difícil" e "difícil"), moderado ("nem fácil, nem difícil") e baixo ("fácil" e "muito fácil"). O Alfa de Cronbach (a) $(0,936)$ indica consistência e robustez interna do questionário. Na Ełapa 3, para a análise da frequência da realização de determinadas habilidades e atitudes, os docentes da amostra foram questionados por meio de outras 22 questões avaliadas com escala Likert de 5 (cinco) pontos: nunca, raramente, algumas vezes, muitas vezes e sempre. O Alfa de Cronbach (a) $(0,886)$ indica consistência (Hair et al., 2019) e robustez interna do questionário.

Na Ełapa 4, procedeu-se a uma análise fatorial. A utilização da análise fatorial foi determinada pelos testes de esfericidade de Bartlett e de adequação da amostra de Kaiser-Meyer-Olkin (KMO), seguidos da análise de confiabilidade e de fidedignidade do constructo por meio do coeficiente Alfa de Cronbach (Field, 2009). Para as variáveis de esforço, o teste de Bartlett apresentou resultado altamente significativo $(p<0,001)$, o que indica haver correlações suficientes para a continuidade da análise (Field, 2009). O teste KMO resultou no valor de 0,930, demonstrando a existência de correlação entre as variáveis e um nível excelente de adequação do modelo fatorial aos dados (Field, 2009). Para as variáveis de frequência, o KMO obtido é de 0,872. O teste de Bartlett para esfericidade é significativo $(p<0,05)$ e o Coeficiente Alfa de Cronbach $(0,886)$ satisfaz o critério recomendado por Hair et al. (2019) para a análise fatorial. Uma vez verificada a possibilidade de utilização da análise fatorial, prosseguiu-se para a extração dos fatores. Para tal, utilizou-se o Diagrama de Declividade - critério Scree Test - e o critério de Kaiser. Adotou-se como critério de percentagem da variância explicada um mínimo de $60 \%$, no intuito de garantir significância para os fatores determinados explicarem, ao menos, tal montante de variância (Hair et al., 2019), o que resultou na extração de 4 (quatro) fatores em relação às variáveis de esforço e de 6 (seis) fatores em relação às variáveis de frequência. 


\section{ANÁLISE E DISCUSSÃO DOS RESULTADOS}

Os resultados da pesquisa estão apresentados em seções: (4.1) Caracterização dos sujeitos da pesquisa, (4.2) Análise do grau de esforço e da frequência para mobilização das competências docentes e (4.3) Matriz de mobilização das competências docentes.

\subsection{Caracterização dos Sujeitos da Pesquisa}

As características demográficas dos sujeitos da pesquisa foram compiladas de forma a compor um panorama geral da amostra, a qual é composta por 243 docentes, dos quais, 194 lecionam disciplinas exclusivas do currículo $(79,8 \%)$ e 49 lecionam outras disciplinas do currículo (20,2\%). Constatou-se uma predominância masculina $(57,6 \%)$ na carreira docente no estado do Rio Grande do Sul, o que vai ao encontro dos achados descritos por Araújo et al. (2015) e Frauches (2015). A idade média dos respondentes $(45,2$ anos) revela uma amostra formada, preponderantemente, por docentes maduros e experientes. A distribuição de frequências das idades, revelou-se uma distribuição razoavelmente simétrica em torno da média (a maior parte dos docentes que participaram das pesquisas possuía entre 30 e 51 anos). Esse resultado também foi evidenciado por Frauches (2015) e por Farias (2016).

O tempo de carreira docente médio dos respondentes é de 13,4 anos. A fase, conforme Huberman (2000), que apresentou maior número de participantes é a de diversificação ou questionamento (64,6\% dos respondentes), seguida da fase de estabilização (16,5\%). A quantidade de docentes em cada fase em muito se assemelha aos achados de Araújo et al. (2015), de Farias e Araújo (2016), de Araújo, Miranda e Pereira (2017) e de Farias et al. (2020), inclusive em relação ao percentual de docentes em cada fase do ciclo. A maior parte dos professores $(82,6 \%)$ não possui dedicação exclusiva à docência; contudo, trabalha mais de 12 horas e menos de 20 horas, o que equivale a um turno diário de dedicação à docência em turmas de 20 e 50 alunos $(77,8 \%)$, sendo que, a maior parte $(86,8 \%)$ leciona exclusivamente em instituições privadas.

No que tange à formação acadêmica, do total da amostra, 166 docentes $(63,8 \%)$ possuem graduação em Ciências Contábeis, $53(20,4 \%)$ em áreas afins (Administração e Economia) e 41 (15,8\%) em outras áreas do conhecimento. Dos docentes participantes da pesquisa, 207 (85,9\%) possuem especialização lato sensu concluída ou em andamento, 212, mestrado concluído ou em andamento $(88,0 \%)$ - dos quais 61 em Ciências Contábeis -, 84, doutorado concluído ou em andamento (34,9\%) - dos quais 8 em Ciências Contábeis - e 4 pós-doutorado concluído $(1,7 \%)$ - dos quais apenas um concluiu em Ciências Contábeis.

O questionamento em relação à formação para a docência no Ensino Superior foi apresentado em formato de assinalação múltipla, podendo ser selecionadas tantas respostas quantas condizentes com a realidade do docente, o que fica demonstrado na Tabela 1. 


\section{Tabela 1}

Formação para a docência

\begin{tabular}{|c|c|c|c|}
\hline \multirow{2}{*}{$\begin{array}{l}\text { Em relação à formação para a docência no Ensino Superior, } \\
\text { indique as opções que você já cursou: (pode haver mais de uma } \\
\text { resposta) }\end{array}$} & \multicolumn{2}{|c|}{ Respostas } & \multirow{2}{*}{$\begin{array}{l}\% \text { de } \\
\text { casos }\end{array}$} \\
\hline & $\mathbf{n}^{\circ}$ & $\%$ & \\
\hline Disciplina de metodologia do Ensino Superior na pós-graduação & 198 & $22,9 \%$ & $81,5 \%$ \\
\hline $\begin{array}{l}\text { Programa de preparação para a docência oferecido pela } \\
\text { Instituição de Ensino Superior que trabalha }\end{array}$ & 141 & $16,3 \%$ & $58,0 \%$ \\
\hline Cursos de capacitação didático-pedagógica & 132 & $15,2 \%$ & $54,3 \%$ \\
\hline Cursos de capacitação técnica & 123 & $14,2 \%$ & $50,6 \%$ \\
\hline Cursos de capacitação educacional (contexto do Ensino Superior) & 90 & $10,4 \%$ & $37,0 \%$ \\
\hline Estágio supervisiona & 67 & $7,7 \%$ & $27,6 \%$ \\
\hline Curso de pós-graduação lato sen. & 49 & $5,7 \%$ & $20,2 \%$ \\
\hline Curso de pós-graduação stricto sensu na área da Educação. & 35 & $4,0 \%$ & $14,4 \%$ \\
\hline $\begin{array}{l}\text { Não frequentou cursos na área da formação para a docência } \\
\text { universitária }\end{array}$ & 26 & $3,0 \%$ & $10,7 \%$ \\
\hline $\begin{array}{l}\text { Outro - curso de graduação na área educacional ou licenciatura } \\
\text { em outras áreas }\end{array}$ & 5 & $0,6 \%$ & $2,1 \%$ \\
\hline Total de observações & 866 & $100 \%$ & - \\
\hline
\end{tabular}

$\mathrm{n}^{\circ}=$ número de respostas.

Fonte: Elaborada pelos autores.

Os resultados indicaram (Tabela 1) que 81,5\% dos docentes da amostra cursaram disciplina de metodologia do Ensino Superior na pós-graduação, 58\% cursaram programa de preparação para a docência oferecido pela Instituição de Ensino Superior que trabalha e 54,3\% participaram de cursos de capacitação didático-pedagógica. Não frequentaram cursos na área da formação para a docência universitária $10,7 \%$ dos docentes da amostra. Os resultados exibem, todavia, uma melhora na qualificação pedagógica dos professores de Ciências Contábeis em relação a resultados de estudos anteriores, sinalizando a preocupação dos docentes do RS com sua formação continuada.

Esses achados revelam o desenvolvimento da qualificação dos docentes na área da Ciência Contábil e podem indicar que, conforme Silva et al. (2019), a disciplina Metodologia do Ensino contribui para a formação dos docentes que estão iniciando a carreira, permitindo-os conhecer conteúdos relevantes referentes à didática e possibilitando sua aplicação em diferentes estratégias de ensino; e, para os docentes que já atuam na docência, propiciando uma reflexão sobre os métodos de ensino e o aperfeiçoamento das técnicas utilizadas no ambiente educacional. Um contato com conteúdo específico do campo da docência poderia possibilitar aos professores dos programas de pós-graduação em Contabilidade a adoção de estratégias de ensino diferenciadas em sala de aula (Barbosa, Leal, \& Nganga, 2019).

Os resultados, em relação ao apoio para participação dos docentes em projetos de pesquisa e em eventos científicos, à oferta e apoio à participação em programas de preparação para a docência, à proposição de atividades que possibilitam o aprimoramento e a capacitação pedagógica do docente e ao incentivo financeiro ao aprimoramento acadêmico ou à participação do docente em eventos, estão demonstrados na Figura 1. 
Competências Docentes: um Estudo com Professores de Graduação em Ciências Contábeis no Rio Grande do Sul

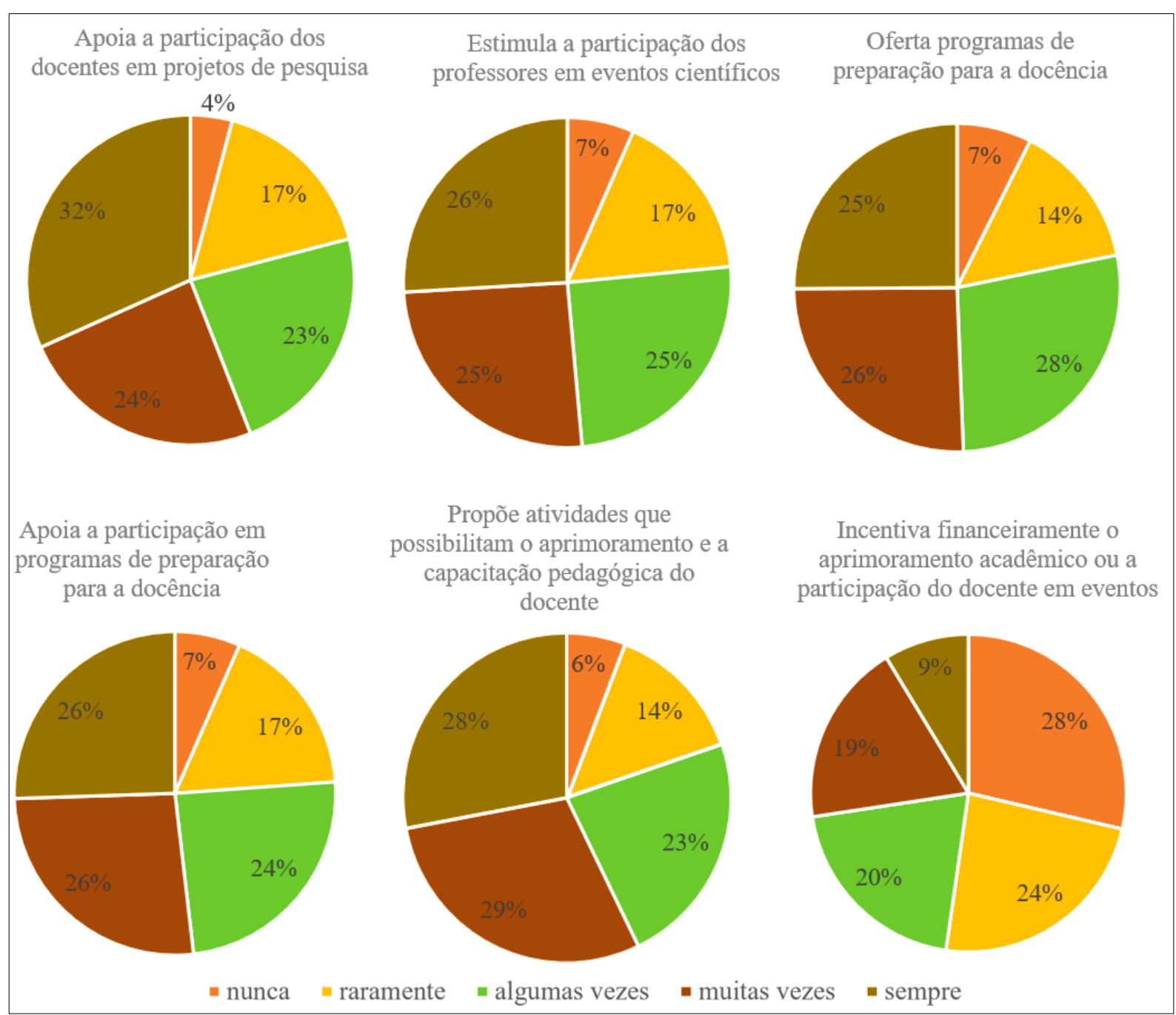

Figura 1 - Frequências em relação às atitudes das IES no apoio de atividades de capacitação Fonte: elaborada a partir dos dados da pesquisa.

Em geral, as IES apoiam a participação dos docentes em projetos de pesquisa, eventos, programas de preparação para a docência, inclusive ofertando essas atividades, e propondo atividades de capacitação pedagógica "sempre" ou "muitas vezes" em $56 \%$ das vezes revelando que existe um grau de preocupação das IES com tais aspectos da formação continuada do professor de Ciências Contábeis. A despeito disso, mais de $50 \%$ dos docentes indicaram que "nunca" ou "raramente" há incentivo financeiro por parte das IES para aprimoramento acadêmico ou para participação em eventos. Percebe-se, a relevância do papel das instituições de ensino no que tange aos investimentos em capacitação pedagógica dos docentes, de forma a prepará-los mais adequadamente para atuarem em sala de aula (Barbosa et al., 2019).

A análise do teste qui-quadrado de Pearson indica que, em relação a apoiar a participação dos docentes em projetos de pesquisa, existe uma associação positiva significativa entre a frequência "sempre" e "instituições públicas" e entre a frequência "raramente" e "instituições privadas". Dessa forma, percebe-se que as instituições públicas de ensino costumam incentivar mais 
frequentemente a participação dos docentes em projetos de pesquisa do que as instituições privadas. Em relação a incentivar financeiramente o aprimoramento acadêmico ou a participação do docente em eventos, verificou-se uma associação positiva significativa entre a frequência "nunca" e "instituições privadas", o que evidencia uma propensão menor das IES privadas a conceder estímulos financeiros para o aprimoramento acadêmico ou para a participação do docente em eventos. Os resultados revelaram, ainda, que as instituições públicas são mais propensas a incentivar financeiramente os docentes a participarem de eventos do que as privadas.

Sob outro aspecto da capacitação docente, a Tabela 2 apresenta a frequência com que os docentes, nos últimos dois anos, participaram de eventos, desenvolveram projetos ou promoveram sua própria formação continuada.

\section{Tabela 2}

Frequência de participação em eventos de educação continuada - em (\%)

\begin{tabular}{|c|c|c|c|c|c|}
\hline Questão (em relação aos últimos dois anos) & Nunca & $\begin{array}{l}\text { Rara- } \\
\text { mente }\end{array}$ & $\begin{array}{l}\text { Algumas } \\
\text { vezes }\end{array}$ & $\begin{array}{c}\text { Muitas } \\
\text { vezes }\end{array}$ & Sempre \\
\hline $\begin{array}{l}\text { Participou de cursos de aperfeiçoamento } \\
\text { técnico }\end{array}$ & 5,0 & 12,0 & 36,9 & 27,8 & 18,3 \\
\hline $\begin{array}{l}\text { Participou de cursos de preparação para a } \\
\text { docência }\end{array}$ & 15,1 & 20,6 & 37,0 & 18,5 & 8,8 \\
\hline $\begin{array}{l}\text { Participou de eventos científicos (congressos, } \\
\text { seminários, simpósios, etc) da área ou de áreas } \\
\text { afins }\end{array}$ & 2,9 & 7,0 & 33,7 & 32,9 & 23,5 \\
\hline $\begin{array}{l}\text { Participou de eventos científicos (congressos, } \\
\text { seminários, simpósios, etc) da área educacional }\end{array}$ & 18,3 & 23,8 & 31,3 & 17,9 & 8,8 \\
\hline Participou de eventos na área pedagógica & 19,7 & 28,2 & 29,1 & 15 & 8,1 \\
\hline Desenvolveu projetos de pesquisa & 11,7 & 18,8 & 30,5 & 18,4 & 20,5 \\
\hline $\begin{array}{l}\text { Teve artigos publicados em eventos científicos } \\
\text { ou periódicos }\end{array}$ & 19,0 & 14,9 & 30,2 & 16,1 & 19,8 \\
\hline Teve livro(s) de sua autoria publicado & 59,7 & 13,1 & 11,9 & 7,2 & 8,1 \\
\hline $\begin{array}{l}\text { Promoveu sua formação pedagógica } \\
\text { continuada }\end{array}$ & 19,2 & 22,2 & 26,4 & 19,2 & 13,0 \\
\hline Promoveu sua formação reflexiva continuada & 13,6 & 22,3 & 26,0 & 23,6 & 14,5 \\
\hline
\end{tabular}

Fonte: Elaborada pelos autores.

Um contingente significativo de docentes na amostra nunca participou de eventos científicos na área educacional (18,3\%), nem teve artigos publicados em eventos científicos ou periódicos (19\%) e raramente ou nunca desenvolveu projetos de pesquisa (18,8\% e $11,7 \%$ respectivamente). Sob outro aspecto da capacitação docente, a participação em cursos de aperfeiçoamento técnico é um item priorizado pelos docentes, tendo em vista que $46,1 \%$ dos professores participam "sempre" ou "muitas vezes" desse tipo de evento. Embora mais de $50 \%$ das IES tenham ofertado programas de preparação para a docência $(79 \%)$ e apoiado a participação nesses programas (76\%), os achados sinalizam para o fato de que participação em cursos de aperfeiçoamento técnico é priorizada em detrimento da participação em cursos de preparação para a docência e em eventos na área pedagógica. Isso indica haver um nível significativo de preocupação para a necessidade de qualificação e aprimoramento técnico. Da mesma forma, a participação dos docentes em cursos de preparação para a 
docência e eventos na área pedagógica ocorre algumas vezes $(36,2 \%$ - 88 docentes), muitas vezes $(18,5 \%)$ e sempre $(8,8 \%)$, totalizando $63,5 \%$ da amostra.

Segundo Marshall, Smith, Dombrowski and Garner (2012), é ideal que haja um equilíbrio entre conhecimentos práticos e teóricos e que o professor esteja sempre buscando atualização, o que envolveria comparecer a eventos profissionais, participar ou ministrar congressos, seminários, conferências acadêmicas ou profissionais, além de publicar artigos. A participação em eventos na área educacional é relevante para os docentes, pois, em geral, esse tipo de atividade permite a discussão de temas atuais, além do contato com profissionais de outras áreas e a troca de informações sobre interesses em comum.

A formação continuada pedagógica e reflexiva, conforme apontado por Libâneo (2008), é relevante para os docentes da área contábil (Lapini, 2012; Miranda et al., 2012). De acordo com Laffin (2005), não deve restringir-se aos cursos de atualização, devendo ser buscada na própria prática diária do docente, no movimento dialético ação-reflexão-ação. Essa aprendizagem permanente deve ser entendida como responsabilidade tanto da instituição, quanto do próprio professor.

As IES, frequentemente (51\%) apoiam a participação dos professores em eventos científicos e (56\%) apoiam sua participação em projetos de pesquisa; a despeito disso, um quantitativo representativo de docentes nunca teve artigos publicados em eventos científicos ou periódicos (19\%) e raramente $(11,7 \%$ ) ou nunca (18,8\%) desenvolveu projetos de pesquisa. Dos respondentes, quase $60 \%$ dos docentes nunca tiveram um livro de sua autoria publicado.

Os docentes, em $40 \%$ das situações, "nunca" ou "raramente" promovem sua formação pedagógica continuada e sua formação reflexiva continuada. Araujo (2017) afirma que o professor de ciências contábeis necessita de formação complementar, uma vez que em sua formação original como bacharelado, não há previsão de preparação para tal e essa formação adviria de cursos de especialização de longa ou curta duração, buscas individuais e da formação acadêmica pelos programas de mestrado e doutorado. Essa formação deveria ser fornecida pelas IES, tendo em vista tratar-se de terreno fértil às colaborações efetivas e à qualificação daqueles que nela estudam e daqueles que nela ensinam (Farias \& Araújo, 2016).

Mais de $50 \%$ dos docentes participaram, nos últimos dois anos, "muitas vezes" (32,9\%) ou "sempre" (23,5\%), de eventos científicos (congressos, seminários, simpósios, entre outros) da área ou de áreas afins e, mais de um quarto $(26,7 \%)$, de eventos científicos da área educacional. De forma mais animadora, os dados revelam que os professores de Ciências Contábeis do RS estão buscando desenvolver suas competências pedagógicas, contrariando estudos anteriores que indicavam reduzido número de docentes que haviam realizado algum curso complementar da área pedagógica ao longo da carreira. Perazo et al. (2016) sinaliza para a existência de uma preocupação maior dos professores em participar de eventos e cursos na sua área de atuação do que na área educacional.

Por sua vez, a Tabela 3, traz informações a respeito de como o docente acredita que suas competências pedagógicas foram desenvolvidas. 


\section{Tabela 3}

Desenvolvimento de competências pedagógicas

\begin{tabular}{lrrr}
\hline Acredita que suas competências pedagógicas foram desenvolvidas: & \multicolumn{2}{c}{ Respostas } & \% de \\
\cline { 2 - 3 } (pode haver mais de uma resposta) & $\mathbf{n}^{\circ}$ & \multicolumn{1}{c}{ casos } \\
\hline A partir de esforços individuais de capacitação docente & 187 & $29,4 \%$ & $77,0 \%$ \\
Nas instituições de ensino onde atua/atuou & 175 & $27,5 \%$ & $72,0 \%$ \\
Em programas de pós-graduação stricto sensu & 115 & $18,1 \%$ & $47,3 \%$ \\
Em programas de pós-graduação lato sensu & 94 & $14,8 \%$ & $38,7 \%$ \\
Na formação básica & 58 & $9,1 \%$ & $23,9 \%$ \\
Não acredita que são necessários cursos formativos específicos para & 7 & $1,1 \%$ & $2,9 \%$ \\
o exercício da docência & $\mathbf{6 3 6}$ & $\mathbf{1 0 0 \%} \mathbf{2 6 1 , 7 \%}$ \\
\hline Total & &
\end{tabular}

$n^{\circ}=$ número de respostas.

Fonte: Elaborada pelos autores.

Os dados levantados demonstram que prepondera, dentre os docentes, a concepção de que o desenvolvimento das competências pedagógicas se dá, precipuamente, a partir de esforços individuais de capacitação docente $(29,4 \%$ das respostas) e nas instituições de ensino onde atua/atuou $(27,5 \%)$.

No que diz respeito à percepção para o exercício da docência, 57,6\% dos professores da amostra indicaram que concordam totalmente com o fato de estarem preparados para o exercício do magistério superior em Ciências Contábeis; $38,3 \%$ concordam em parte e 3,3\% discordam parcial ou totalmente da afirmação. Assim, a maior parte dos docentes $(95,9 \%)$ julga estar mais preparada do que despreparada para o exercício do magistério superior, de forma que os achados se assemelham, em parte, aos de Farias (2016).

Prepondera, entre os docentes, a concepção de que o desenvolvimento das competências pedagógicas se dá, precipuamente, a partir de esforços individuais de capacitação docente (29,4\% das respostas) e nas instituições de ensino onde atua/atuou (27,5\%). Dos professores de Ciências Contábeis no RS 77\% buscaram, por meio de iniciativas próprias, sua capacitação e o desenvolvimento de suas competências docentes. Da mesma maneira, $72 \%$ dos docentes acreditam que suas competências pedagógicas foram desenvolvidas a partir de iniciativas das instituições de ensino de atuação, mas apenas 47,3\% dos respondentes assinalaram que isso ocorrev em programas de pós-graduação stricto sensu.

No geral, os dados confirmam os achados de Swain e Stout (2000) e de Slomski (2009), quando afirmam que a maior parte dos esforços para o desenvolvimento de competências didático-pedagógicas na formação de docentes baseia-se no esforço individual. Da mesma forma, corrobora os achados de Farias (2016) e de Farias et al. (2020), quando afirmam que o efeito da formação obtida a partir de interesse próprio é maior do que a responsabilidade que o indivíduo deveria ter nesse aspecto; ou seja, que a formação por interesse próprio vem suprindo a busca pela formação docente. Esse resultado corrobora os três fatores elencados por Farias et al. (2020), como possíveis espaços formativos para a docência: Programas de Pós-Graduação, Instituição de Ensino Superior - IES (como espaço laboral) e autoformação.

Além disso, apesar da pesquisa demonstrar haver significativa contribuição dos Programas de Pós-graduação stricto sensu em Contabilidade para a formação pedagógica - embora o foco desses espaços formativos esteja mais 
relacionado à formação do pesquisador (Slomski et al., 2013; Nganga et al., 2016) -, o percentual de casos revela que há maior relevância do desenvolvimento das competências pedagógicas por meio de esforços individuais e no espaço laboral. Os resultados sugerem, ainda, no mesmo sentido dos achados de Farias et al. (2020) e de Farias e Araujo (2016), que autoformação é o espaço formativo que mais contribui para o desenvolvimento da formação para a docência.

Por outro lado, a análise demonstra que, diferentemente da realidade apresentada por Farias at al. (2020) - os quais relatam incipientes iniciativas, isoladas, geralmente de caráter pontual e, em sua maior parte, gestadas e realizadas em âmbito institucional -, as Instituições de Ensino Superior como lócus profissional representam, no RS, um importante espaço formativo - talvez não suficiente - no desenvolvimento das competências docentes e no aperfeiçoamento das atividades de ensino. Fato é que deve ser destacada a relevância da criação de oportunidades e espaços de formação de professores onde seja possível o desenvolvimento de competências didático-pedagógicas (Hillen, Laffin, \& Ensslin, 2018) e que, também é papel das IES enquanto espaço profissional, investir mais na capacitação pedagógica dos seus docentes, de forma a prepará-los de maneira mais adequada para a atuação em sala de aula.

Todavia, como o desenvolvimento profissional docente ocorre por meio de um processo não linear, não há consenso a respeito de como esse processo pode ser abordado nos programas de formação docente (Farias \& Araujo, 2018). No que diz respeito à formação dos docentes em programas de pós-graduação stricto sensu, apesar da baixa oferta de disciplinas que auxiliam na formação pedagógica, observa-se que $18,1 \%$ das respostas indicam esse espaço formativo como relevante para o desenvolvimento das competências pedagógicas, o que confirma os achados de Silva, Ferreira, Leal e Miranda (2019). No mesmo sentido, surge a necessidade de (re)pensar a inserção profissional de novos docentes, bem como sua formação acrítica e tecnicista, além de trazer à tona reflexões a respeito do papel do docente perante as novas gerações, seus novos desafios e - papel as instituições de ensino na sua preparação mais adequada para atuação em sala de aula (Lima \& Araujo, 2019).

\subsection{Análise do Grau de Esforço e da Frequência para Mobilização das Competências Docentes}

No âmbito da prática pedagógica, as questões da análise da percepção do esforço para mobilização das competências docentes estão apresentadas na Tabela 4. 


\section{Tabela 4}

Questões de percepção do esforço de mobilização das competências docentes

\begin{tabular}{|c|c|c|c|}
\hline $\begin{array}{l}\text { Dimensão das } \\
\text { competências }\end{array}$ & Questão & $\begin{array}{c}\text { Média } \\
(\mu)\end{array}$ & \begin{tabular}{|c} 
Desvio \\
Padrão \\
$(\sigma)$
\end{tabular} \\
\hline Pedagógica & $\begin{array}{l}\text { 1. Planejo e organizo as atividades de ensino a partir de como penso } \\
\text { que o conhecimento acontece }\end{array}$ & 2,91 & 0,856 \\
\hline Pedagógica & $\begin{array}{l}\text { 2. Concebo as atividades de ensino considerando as teorias de } \\
\text { aprendizagem sob a perspectiva pedagógica }\end{array}$ & 2,68 & 0,887 \\
\hline Tecnológica & $\begin{array}{l}\text { 3. Preparo material didático de apoio às atividades do curso com a } \\
\text { utilização das tecnologias da informação e comunicação }\end{array}$ & 3,04 & 0,906 \\
\hline Técnica & $\begin{array}{l}\text { 4. Acompanho mudanças que envolvem os conhecimentos } \\
\text { técnicos das disciplinas que ministro }\end{array}$ & 2,91 & 0,939 \\
\hline Tecnológica & 5. Exploro novos ambientes tecnológicos de aprendizagem & 2,70 & 0,830 \\
\hline Técnica & $\begin{array}{l}\text { 6. Aplico os conteúdos da(s) disciplina(s) que ministro com suficiente } \\
\text { domínio técnico }\end{array}$ & 3,19 & 0,940 \\
\hline Técnica & $\begin{array}{l}\text { 7. Relaciono os conteúdos ministrados em aula com os de outras } \\
\text { disciplinas do curso e/ou outras áreas do saber }\end{array}$ & 3,23 & 0,885 \\
\hline Técnica & $\begin{array}{l}\text { 8. Relaciono os conteúdos ministrados em aula com conhecimentos } \\
\text { construídos na prática docente e na prática profissional }\end{array}$ & 3,44 & 0,886 \\
\hline Reflexão & $\begin{array}{l}\text { 9. Reflito com os alunos sobre os conteúdos ministrados em sala de } \\
\text { aula e sobre aspectos globais da ciência e da sociedade }\end{array}$ & 3,07 & 0,888 \\
\hline Comunicação & 10. Informo e envolvo os alunos em minhas aulas & 2,86 & 1,005 \\
\hline & $\begin{array}{l}\text { 11. Comunico-me com clareza e objetividade, fazendo-me } \\
\text { entender facilmente }\end{array}$ & 3,11 & 0,947 \\
\hline Comunic & $\begin{array}{l}\text { 12. Utilizo diferentes estratégias de comunicação nas aulas (diálogo, } \\
\text { conversação, interlocução, escrita) }\end{array}$ & 3,10 & 0,885 \\
\hline Didática & 13. Dou suporte aos alunos em tarefas cognitivas & 2,98 & 0,818 \\
\hline Comunicação & 14. Apresento prontidão para atender às demandas dos alunos & 3,32 & 0,888 \\
\hline Comunicação & 15. Incentivo o pensamento crítico dos alunos & 2,74 & 1,068 \\
\hline Didática & 16. Incentivo e desafio os alunos à busca de novos conhecimentos & 2,69 & 1,056 \\
\hline Didática & 17. Exercito a mediação pedagógica e assessoro os alunos & 2,85 & 0,810 \\
\hline Pedagógica & $\begin{array}{l}\text { 18. Aplico, em sala de aula, conhecimentos das teorias de ensino e } \\
\text { aprendizagem }\end{array}$ & 2,75 & 0,831 \\
\hline Tecnológica & 19. Aplico novas tecnologias no processo de ensino e aprendizagem & 2,72 & 0,810 \\
\hline Tecnológica & 20. Mantenho-me tecnologicamente atualizado & 2,80 & 0,915 \\
\hline Reflexão & $\begin{array}{l}\text { 21. Reflito a respeito de minha prática docente antes, durante ou } \\
\text { depois da ação }\end{array}$ & 2,84 & 0,859 \\
\hline Reflexão & 22. Promovo melhorias no processo de ensino-aprendizagem & 2,69 & 0,843 \\
\hline
\end{tabular}

Fonte: Elaborada pelos autores.

A análise da percepção do esforço necessário para operacionalizar determinadas competências docentes revela que, em quatorze (14) questões, os professores julgam possuir mais dificuldades do que facilidades; ou seja, em 63,6\% das competências, os docentes apresentaram altos graus de dificuldades para operacionalizar as competências docentes. Os docentes julgaram ter mais facilidades em relação a questionamentos no âmbito das competências técnica (6, 7 e 8) e de comunicação (11, 12 e 14). Em relação às competências reflexiva (9) e tecnológica (3), em duas questões percebeu-se o dispêndio de baixo esforço para mobilização das competências docentes. Para todas as questões relacionadas às competências pedagógica (1,2 e 18) e didática (questões 13, 16 e 17) verificou-se o dispêndio de altos graus de esforço para tal, da mesma forma que a maior parte das questões reflexivas $(15,21$ e 22) e tecnológicas (5, 
19 e 20). Portanto, em média, os docentes apresentaram altos índices de esforços para mobilizar as competências docentes $(\mu=2,939$ e $\sigma=0,898)$, o que indica haver, proporcionalmente, mais docentes com dificuldades do que com facilidades para tal.

Quanto ao resultado da análise das frequências relativas para mobilização das competências docentes (classificado em alto, moderado e baixo) evidencia que, em média, os professores de Ciências Contábeis no Rio Grande do Sul operacionalizam suas competências docentes com alta frequência $(\mu=4,23$ e $\sigma=0,721$ ). Esse dado vai de encontro aos achados de Swain e Stout (2000) de que a maioria dos docentes não estaria adequadamente preparada para ensinar. Além de julgarem-se preparados para tal, os docentes operacionalizam habilidades e atitudes com alta frequência. Os resultados da frequência apresentada na operacionalização das competências docentes podem ser considerados estratégicos e determinantes para a consolidação da prática curricular no contexto de sala de aula e estariam, segundo Verdum (2013), intimamente associados à formação docente e à construção dos saberes do professor.

\subsection{Matriz de Mobilização das Competências Docentes}

A mobilização das competências docentes foi analisada no âmbito do esforço e da frequência e, para tal, foram construídas duas matrizes (percepção do esforço e frequência) com base na análise fatorial realizada. Os resultados estão apresentados nas subseções a seguir.

\subsubsection{Matriz de Percepção do Esforço}

Os resultados obtidos na Matriz de Cargas Fatoriais indicam que o Fator 1 possui pesos mais altos nas variáveis: 16, 15, 17, 10, 13, 11, 22, 14 e 21. O segundo fator compreende um grupo de cinco variáveis: $7,8,6,9$ e 12. O terceiro fator engloba as variáveis: 19, 20 e 18. O quarto e último fator reúne as variáveis: 2, 1, 4 e 3. Para os fatores extraídos, todos os alfas foram superiores a 0,7 , o que é considerado altamente satisfatório, haja vista o limite inferior de aceitabilidade de 0,6, conforme Hair et al. (2019).

Levando em consideração os fatores resultantes da análise fatorial, elaborou-se a Matriz da Percepção do Esforço para Mobilização das Competências Docentes pelos professores de graduação em Ciências Contábeis no Rio Grande do Sul. A Tabela 5 apresenta a matriz indicando os fatores decorrentes da análise estatística, uma descrição criada para cada fator, o número da questão e o questionamento que constaram no instrumento de coleta de dados e a indicação da competência docente a que pertence, conforme Vendruscolo (2015). 


\section{Tabela 5}

Matriz da percepção do esforço para mobilização das competências docentes pelos professores de graduação em Ciências Contábeis no Rio Grande do Sul

\begin{tabular}{|c|c|c|c|c|c|}
\hline$\frac{\overline{0}}{0}$ & $\begin{array}{l}\text { Denominação } \\
\text { do fator }\end{array}$ & $\begin{array}{ll}0 & \frac{c}{u} \\
\frac{1}{0} & 0 \\
0 & \frac{0}{c} \\
\frac{0}{4} & \frac{1}{U}\end{array}$ & $\frac{0}{\frac{10}{4}}$ & $\begin{array}{l}\text { Questionamentos que fazem parte do fator } \\
\text { (percepção de esforço) }\end{array}$ & Competência \\
\hline \multirow{9}{*}{1} & \multirow{9}{*}{$\begin{array}{c}\text { Saber ser } \\
\text { professor e } \\
\text { mediar o } \\
\text { processo de } \\
\text { ensino e } \\
\text { aprendizagem }\end{array}$} & \multirow{9}{*}{0,881} & 16 & $\begin{array}{l}\text { Incentivo e desafio os alunos à busca de novos } \\
\text { conhecimentos }\end{array}$ & Didática \\
\hline & & & 15 & Incentivo o pensamento crítico dos alunos & Comunicação \\
\hline & & & 17 & $\begin{array}{l}\text { Exercito a mediação pedagógica e assessoro } \\
\text { os alunos }\end{array}$ & Didática \\
\hline & & & 10 & Informo e envolvo os alunos em minhas aulas & Comunicação \\
\hline & & & 13 & Dou suporte aos alunos em tarefas cognitivas & Didática \\
\hline & & & 11 & $\begin{array}{l}\text { Comunico-me com clareza e objetividade, } \\
\text { fazendo-me entender facilmente }\end{array}$ & Comunicação \\
\hline & & & 22 & $\begin{array}{l}\text { Promovo melhorias no processo de ensino- } \\
\text { aprendizagem }\end{array}$ & Reflexão \\
\hline & & & 14 & $\begin{array}{l}\text { Apresento prontidão para atender às } \\
\text { demandas dos alunos }\end{array}$ & Comunicação \\
\hline & & & 21 & $\begin{array}{l}\text { Reflito a respeito de minha prática docente } \\
\text { antes, durante ou depois da ação }\end{array}$ & Reflexão \\
\hline \multirow{5}{*}{2} & \multirow{5}{*}{$\begin{array}{c}\text { Domínio e } \\
\text { comunicação } \\
\text { do conteúdo } \\
\text { específico }\end{array}$} & \multirow{5}{*}{0,840} & 7 & $\begin{array}{l}\text { Relaciono os conteúdos ministrados em aula } \\
\text { com os de outras disciplinas do curso e/ou } \\
\text { outras áreas do saber }\end{array}$ & Técnica \\
\hline & & & 8 & $\begin{array}{l}\text { Relaciono os conteúdos ministrados em aula } \\
\text { com conhecimentos construídos na prática } \\
\text { docente e na prática profissional }\end{array}$ & Técnica \\
\hline & & & 6 & $\begin{array}{l}\text { Aplico os conteúdos da(s) disciplina(s) que } \\
\text { ministro com suficiente domínio técnico }\end{array}$ & Técnica \\
\hline & & & 9 & $\begin{array}{l}\text { Reflito com os alunos sobre os conteúdos } \\
\text { ministrados em sala de aula e sobre aspectos } \\
\text { globais da ciência e da sociedade }\end{array}$ & Reflexão \\
\hline & & & 12 & $\begin{array}{l}\text { Utilizo diferentes estratégias de comunicação } \\
\text { nas aulas (diálogo, conversação, interlocução, } \\
\text { escrita) }\end{array}$ & Comunicação \\
\hline \multirow{4}{*}{3} & \multirow{4}{*}{$\begin{array}{c}\text { Conhecimentos } \\
\text { de tecnologia } \\
\text { da informação } \\
\text { para melhoria } \\
\text { do processo de } \\
\text { ensino }\end{array}$} & \multirow{4}{*}{0,826} & 19 & $\begin{array}{l}\text { Aplico novas tecnologias no processo de } \\
\text { ensino e aprendizagem }\end{array}$ & Tecnológica \\
\hline & & & 20 & Mantenho-me tecnologicamente atualizado & Tecnológica \\
\hline & & & 5 & $\begin{array}{l}\text { Exploro novos ambientes tecnológicos de } \\
\text { aprendizagem }\end{array}$ & Tecnológica \\
\hline & & & 18 & $\begin{array}{l}\text { Aplico, em sala de aula, conhecimentos das } \\
\text { teorias de ensino e aprendizagem }\end{array}$ & Pedagógica \\
\hline \multirow{4}{*}{4} & \multirow{4}{*}{$\begin{array}{c}\text { Dominar as } \\
\text { teorias de } \\
\text { aprendizado, } \\
\text { saber pensar } \\
\text { criticamente } \\
\text { sobre elas e } \\
\text { aplicá-las na } \\
\text { prática } \\
\text { docente }\end{array}$} & \multirow{4}{*}{0,770} & 2 & $\begin{array}{l}\text { Concebo as atividades de ensino } \\
\text { considerando as teorias de aprendizagem sob } \\
\text { a perspectiva pedagógica }\end{array}$ & Pedagógica \\
\hline & & & 1 & $\begin{array}{l}\text { Planejo e organizo as atividades de ensino a } \\
\text { partir de como penso que o conhecimento } \\
\text { acontece }\end{array}$ & Pedagógica \\
\hline & & & 4 & $\begin{array}{l}\text { Acompanho mudanças que envolvem os } \\
\text { conhecimentos técnicos das disciplinas que } \\
\text { ministro }\end{array}$ & Técnica \\
\hline & & & 3 & $\begin{array}{l}\text { Preparo material didático de apoio às } \\
\text { atividades do curso com a utilização das } \\
\text { tecnologias da informação e comunicação } \\
\text { (TIC) }\end{array}$ & Tecnológica \\
\hline
\end{tabular}


Fator 1 -Saber ser professor e mediar o processo de ensino e aprendizagem - explica 19,04\% da variabilidade total e decorre de nove questões relacionadas com o domínio de elementos das competências didática e de comunicação. A questão com maior carga fatorial é a 16 (0,776): "Incentivo e desafio os alunos à busca de novos conhecimentos". O fator está relacionado, precipuamente, ao papel que o docente exerce enquanto mediador do processo de ensino e aprendizagem, auxiliando o aluno a buscar conhecimentos e construí-los, além da preocupação com o entendimento dos alunos.

Fator 2 - Domínio e comunicação do conteúdo específico - explica 16,09\% da variabilidade total e decorre de cinco questões relacionadas ao domínio do docente na aplicação e na forma de comunicação dos conteúdos específicos da disciplina. A questão com maior carga fatorial é a $7(0,788)$ : "Relaciono os conteúdos ministrados em aula com os de outras disciplinas do curso e/ou outras áreas do saber". Esse fator está relacionado, também, à preocupação do docente com a formação global do profissional, pois o aluno é visto como um futuro profissional no mercado, que terá de lidar com situações diversas e multidisciplinares.

Fator 3 - Conhecimentos de tecnologia da informação para melhoria do processo de ensino - explica $13,7 \%$ da variabilidade total e decorre de quatro questões relacionadas a conhecimentos de tecnologia da informação para melhoria do processo de ensino e à aplicação das teorias de ensino e aprendizagem. A questão com maior carga fatorial é a 19 (0,818): "Aplico novas tecnologias no processo de ensino e aprendizagem". Este fator está relacionado à capacidade do docente em manter-se atualizado em relação a essas tecnologias empregadas no processo de ensino, ao conhecimento de tecnologia da informação para melhoria do processo de ensino e à aplicação das teorias de ensino e aprendizagem. O relacionamento das questões permite perceber que o docente busca esforçar-se para entrar em contato como mundo e com a bagagem do aluno, que vive em época de constante aprimoramento tecnológico, além de buscar formas de engajamento, de cativar o aluno e facilitar seu aprendizado e interesse.

Fator 4 - Dominar as teorias de aprendizado, saber pensar criticamente sobre elas e aplicá-las na prática docente - explica $11,77 \%$ da variabilidade total e decorre de quatro questões relacionadas a conhecimentos pedagógicos e do domínio das teorias de aprendizado. A questão com maior carga fatorial é a 2 $(0,743)$ : "Concebo as atividades de ensino considerando as teorias de aprendizagem sob a perspectiva pedagógica". Esse fator está ligado à concepção de atividades de ensino e conhecimentos técnicos e tecnológicos como pressupostos para o planejamento e concepção das atividades de ensino de forma adequada. As competências que se evidenciaram estão interrelacionadas e exteriorizam, em conjunto, relacionamento com o conhecimento, com o domínio de teorias de aprendizado, com o saber pensar criticamente sobre elas e aplicá-las na prática docente, além do saber utilizar recursos que facilitam a comunicação e a interação com os alunos e que o auxiliam no planejamento de aulas mais atrativas aos discentes e capazes de facilitar seu aprendizado e aumentar seu interesse na disciplina. 


\subsubsection{Matriz de Frequências}

Os resultados obtidos na Matriz de Cargas Fatoriais indicam que o Fator 1 possui pesos mais altos nas variáveis 2, 18, 17 e 22. Este fator apresentou Alfa de Cronbach de 0,788. O Fator 2 inclui as variáveis: 3, 5, 20 e 19, com Alfa de Cronbach de 0,810. O Fator 3 engloba as variáveis: 15, 16 e 10, com Alfa de Cronbach de 0,703. O Fator 4 compreende um grupo de cinco variáveis: 14, 13, 1, 11 e 12, com Alfa de Cronbach de 0,609. O Fator 5 reúne as variáveis: 7, 9, 8 e 21, com Alfa de Cronbach de 0,656. O Fator 6 inclui apenas duas variáveis: 6 e 4, com Alfa de Cronbach de 0,610. Assim, os testes de confiabilidade Alfa de Cronbach dos fatores foram superiores ao limite inferior de aceitabilidade $(0,6) 0$ que é considerado satisfatório de acordo com Hair et al. (2019).

Tendo em vista os fatores resultantes da análise fatorial, elaborou-se a Matriz de Frequência de Mobilização das Competências Docentes pelos professores de graduação em Ciências Contábeis no Rio Grande do Sul. A Tabela 6 apresenta tal matriz, indicando o fator decorrente da análise estatística, seguido de uma descrição criada para cada fator, o número da questão no instrumento de coleta de dados, o próprio questionamento e a indicação da competência docente a que pertence, conforme Vendruscolo (2015).

\section{Tabela 6}

Matriz de Frequência de Mobilização das Competências Docentes pelos professores de graduação em Ciências Contábeis no Rio Grande do Sul

\begin{tabular}{|c|c|c|c|c|c|}
\hline 흠 & $\begin{array}{l}\text { Denominação } \\
\text { do fator }\end{array}$ & 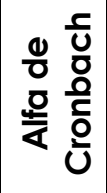 & 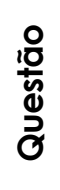 & Questionamentos que fazem parte do fator & Competência \\
\hline \multirow{4}{*}{1} & \multirow{4}{*}{$\begin{array}{l}\text { Processo de } \\
\quad \text { ensino }\end{array}$} & \multirow{4}{*}{0,788} & 2 & $\begin{array}{l}\text { Concebo as atividades de ensino } \\
\text { considerando as teorias de aprendizagem sob } \\
\text { a perspectiva pedagógica }\end{array}$ & Pedagógica \\
\hline & & & 18 & $\begin{array}{l}\text { Aplico, em sala de aula, conhecimentos das } \\
\text { teorias de ensino e aprendizagem }\end{array}$ & Pedagógica \\
\hline & & & 17 & $\begin{array}{l}\text { Exercito a mediação pedagógica e assessoro } \\
\text { os alunos }\end{array}$ & Didática \\
\hline & & & 22 & $\begin{array}{l}\text { Promovo melhorias no processo de ensino- } \\
\text { aprendizagem }\end{array}$ & Reflexão \\
\hline \multirow{4}{*}{2} & \multirow{4}{*}{$\begin{array}{l}\text { Tecnologias da } \\
\text { informação }\end{array}$} & \multirow{4}{*}{0,810} & 3 & $\begin{array}{l}\text { Preparo material didático de apoio às } \\
\text { atividades do curso com a utilização das } \\
\text { tecnologias da informação e comunicação } \\
\text { (TIC) }\end{array}$ & Tecnológica \\
\hline & & & 5 & $\begin{array}{l}\text { Exploro novos ambientes tecnológicos de } \\
\text { aprendizagem }\end{array}$ & Tecnológica \\
\hline & & & 20 & Mantenho-me tecnologicamente atualizado & Tecnológica \\
\hline & & & 19 & $\begin{array}{l}\text { Aplico novas tecnologias no processo de } \\
\text { ensino e aprendizagem }\end{array}$ & Tecnológica \\
\hline \multirow{3}{*}{3} & \multirow{3}{*}{$\begin{array}{l}\text { Envolvimento e } \\
\text { desenvolvimento } \\
\text { do aluno }\end{array}$} & \multirow{3}{*}{0,703} & 15 & Incentivo o pensamento crítico dos alunos & Reflexão \\
\hline & & & 16 & $\begin{array}{l}\text { Incentivo e desafio os alunos à busca de novos } \\
\text { conhecimentos }\end{array}$ & Didática \\
\hline & & & 10 & Informo e envolvo os alunos em minhas aulas & Comunicação \\
\hline
\end{tabular}


Competências Docentes: um Estudo com Professores de Graduação em Ciências Contábeis no Rio Grande do Sul

\begin{tabular}{|c|c|c|c|c|c|}
\hline 혼 & $\begin{array}{l}\text { Denominação } \\
\text { do fator }\end{array}$ & 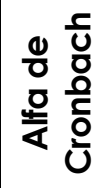 & $\begin{array}{l}\frac{0}{10} \\
\frac{1}{y} \\
\stackrel{0}{0}\end{array}$ & Questionamentos que fazem parte do fator & Competência \\
\hline \multirow{5}{*}{4} & \multirow{5}{*}{$\begin{array}{l}\text { Comunicação } \\
\text { com o aluno }\end{array}$} & \multirow{5}{*}{0,609} & 14 & $\begin{array}{l}\text { Apresento prontidão para atender às } \\
\text { demandas dos alunos }\end{array}$ & Comunicação \\
\hline & & & 13 & Dou suporte aos alunos em tarefas cognitivas & Didática \\
\hline & & & 1 & $\begin{array}{l}\text { Planejo e organizo as atividades de ensino a } \\
\text { partir de como penso que o conhecimento } \\
\text { acontece }\end{array}$ & Pedagógica \\
\hline & & & 11 & $\begin{array}{l}\text { Comunico-me com clareza e objetividade, } \\
\text { fazendo-me entender facilmente }\end{array}$ & Comunicação \\
\hline & & & 12 & $\begin{array}{l}\text { Utilizo diferentes estratégias de comunicação } \\
\text { nas aulas (diálogo, conversação, interlocução, } \\
\text { escrita) }\end{array}$ & Comunicação \\
\hline \multirow{4}{*}{5} & \multirow{4}{*}{$\begin{array}{l}\text { Conteúdos - } \\
\text { reflexão e } \\
\text { relacionamento }\end{array}$} & \multirow{4}{*}{0,656} & 7 & $\begin{array}{l}\text { Relaciono os conteúdos ministrados em aula } \\
\text { com os de outras disciplinas do curso e/ou } \\
\text { outras áreas do saber }\end{array}$ & Técnica \\
\hline & & & 9 & $\begin{array}{l}\text { Reflito com os alunos sobre os conteúdos } \\
\text { ministrados em sala de aula e sobre aspectos } \\
\text { globais da ciência e da sociedade }\end{array}$ & Reflexão \\
\hline & & & 8 & $\begin{array}{l}\text { Relaciono os conteúdos ministrados em aula } \\
\text { com conhecimentos construídos na prática } \\
\text { docente e na prática profissional }\end{array}$ & Técnica \\
\hline & & & 21 & $\begin{array}{l}\text { Reflito a respeito de minha prática docente } \\
\text { antes, durante ou depois da ação }\end{array}$ & Reflexão \\
\hline \multirow[b]{2}{*}{6} & \multirow[b]{2}{*}{ Técnica } & \multirow[b]{2}{*}{0,610} & 6 & $\begin{array}{l}\text { Aplico os conteúdos da(s) disciplina(s) que } \\
\text { ministro com suficiente domínio técnico }\end{array}$ & Técnica \\
\hline & & & 4 & $\begin{array}{l}\text { Acompanho mudanças que envolvem os } \\
\text { conhecimentos técnicos das disciplinas que } \\
\text { ministro }\end{array}$ & Técnica \\
\hline
\end{tabular}

Fonte: Elaborada pelos autores.

A análise fatorial da frequência não resultou nos mesmos fatores que a análise fatorial da percepção do esforço, pois a dificuldade ou a facilidade em relação a determinado componente de competência está associada ao grau de conhecimento ou desconhecimento para sua realização; contudo, a frequência com que determinado elemento de competência é praticado independe do domínio técnico desse elemento.

Fator 1 - Processo de ensino - explica 12,15\% da variabilidade total e decorre de quatro questões relacionadas com o processo de ensino e com atividades de ensino. A questão com maior carga fatorial é a $2(0,846)$ : "Concebo as atividades de ensino considerando as teorias de aprendizagem sob a perspectiva pedagógica". $\bigcirc$ fator indica que o professor conhece as teorias de aprendizagem e está disposto a aplicá-las no ensino.

Fator 2 - Tecnologias da informação - explica 11,57\% da variabilidade total e decorre de quatro questões relacionadas com a utilização de novas tecnologias no processo de ensino, a manter-se atualizado em relação a elas. A questão com maior carga fatorial é a $3(0,796)$ : "Preparo material didático de 
apoio às atividades do curso com a utilização das tecnologias da informação e comunicação (TIC)". O fator indica que o professor aplica técnicas modernas de aprendizado que vão além da obsoleta sala de aula para despertar o interesse dos alunos e mantê-los conectados ao processo de aprendizagem.

Fator 3 - Envolvimento e desenvolvimento do aluno - explica 10,21\% da variabilidade total e decorre de três questões relacionadas ao envolvimento e desenvolvimento dos alunos. A questão com maior carga fatorial é a $15(0,767)$ : "Incentivo o pensamento crítico dos alunos". O fator indica que o professor realmente se importa com os alunos e com o aprendizado deles e, sobretudo, com a formação dos profissionais que eles serão no futuro buscando instigá-los ao pensamento crítico e a busca de novos conhecimentos.

Fator 4 - Comunicação com o aluno - explica 9,42\% da variabilidade total e decorre de cinco questões relacionadas com a comunicação e diálogo com os alunos. A questão com maior carga fatorial é a 14 (0,714): "Apresento prontidão para atender às demandas dos alunos". O fator indica que o professor busca moldar sua forma de comunicação e interação com os alunos no planejamento da atividade de ensino como forma de alcançar o ponto ótimo do aprendizado. Mostra que o docente se preocupa com o aprendizado e, sobretudo, com a compreensão dos conteúdos e com a forma como se dá a aquisição de conhecimentos.

Fator 5 - Conteúdos - reflexão e relacionamento - explica 8,98\% da variabilidade total e decorre de quatro questões relacionadas com a reflexão dos conteúdos e da prática docente e o relacionamento dos conteúdos com outros conhecimentos. A questão com maior carga fatorial é a $7(0,695)$ : "Relaciono os conteúdos ministrados em aula com os de outras disciplinas do curso e/ou outras áreas do saber". O fator indica que o professor capacita alunos para serem profissionais uma vez que, na prática da profissão, todas as disciplinas interagem tanto entre si quanto com fatores externos, e estimular a multidisciplinariedade direciona para tal.

Fator 6 - Técnica - explica 7,72\% da variabilidade total e decorre de duas questões relacionadas com o domínio técnico dos conteúdos ministrados e atualização em relação a eles. A questão com maior carga fatorial é a $6(0,763)$ : "Aplico os conteúdos da(s) disciplina(s) que ministro com suficiente domínio técnico". O fator indica que o professor está constantemente em busca de aprimoramento técnico e didático e demonstra engajamento com o tema da disciplina e com o processo educacional em si.

\subsubsection{Análises das Matrizes de Percepção do Esforço e de Frequências}

As matrizes de percepção do esforço e de frequência demonstram os fatores e as suas correspondentes cargas fatoriais utilizando a rotação Varimax padronizada. Tal análise permite identificar os componentes (questionamentos) que tiveram maior poder de influência na distribuição de cada um dos fatores, determinando seu conteúdo. Esses componentes estão demonstrados nas matrizes (Tabelas 5 e 6), em ordem decrescente de relevância em cada fator.

A variância dos Fatores 1 e 2 explicam 35,14\% da variância rotacionada em relação à percepção do esforço e $23,72 \%$ em relação à frequência. Quanto maior o percentual da variância explicada, maior a importância dele para a 
percepção do esforço. Embora, os fatores contribuam de maneiras distintas para a percepção do esforço e da frequência na mobilização das competências docentes, todos os fatores da análise demonstraram-se relevantes para tal.

A análise fatorial permitiu identificar o questionamento que apresentou maior relevância na composição de cada fator. Quanto às variáveis de esforço, verificou-se que os Fatores 1 e 2 são compostos por elementos de competências de cunho técnico, de comunicação e didático e reflexivo, enquanto os Fatores 3 e 4 são compostos por elementos de competências de cunho tecnológico e pedagógico. Ou seja, o perfil dos docentes da amostra é o de professores que sabem ser professores e mediar 0 processo de ensino e aprendizagem e apresentam domínio e comunicação do conteúdo específico. Contudo, conhecer tecnologia da informação para melhoria do processo de ensino e dominar as teorias de aprendizado, saber pensar criticamente sobre elas e aplicálas na prática docente ocupam espaço limitado no contexto vivido pelos docentes. Isso corrobora os achados de Slosmki et al. (2009), Araujo (2017), Silva e Bruni (2017), Vendruscolo (2017), Alves e D'Souza (2018), Hillen et al. (2018), Lima e Araujo (2019), Farias et al. (2020) e Araújo et al. (2021), indicando que competências como a pedagógica e a tecnológica ainda são consideradas menos desenvolvidas entre os docentes, ao contrário das competências técnica, de comunicação, didática e reflexiva, as quais são consideradas mais desenvolvidas entre os docentes.

No que tange às variáveis de frequência, no Fator 1, a questão que apresentou maior relevância diz respeito à competência pedagógica e no Fator 2 , são relativas à competência tecnológica. Isso significa que, na concepção dos respondentes, o esforço para mobilização das competências docentes é maior em relação às competências didática, de comunicação e técnica e menor para as competências tecnológica e pedagógica. Por outro lado, a análise das frequências de mobilização das competências docentes revelou que, na concepção dos respondentes, as competências pedagógica e tecnológica são mais frequentemente mobilizadas do que as competências de reflexão, comunicação e técnica.

O resultado da análise fatorial revela que a mobilização das competências docentes pelos professores de graduação em Ciências Contábeis no RS ocorre por meio das diversas combinações dos elementos das competências docentes. Os achados da pesquisa indicam, ainda, que as competências mais frequentemente demandadas pelos docentes são também aquelas que requerem maiores esforços para sua mobilização. Embora haja maior frequência de mobilização das competências pedagógica e tecnológica, há um esforço maior na operacionalização das competências didáticas, de comunicação e técnica, resultados esses capazes de sugerir que, apesar da busca pelo aprimoramento e desenvolvimento das competências docentes, os problemas relacionados a elas persistem atuais e necessitam de aprimoramentos.

\section{CONCLUSÕES}

A presente pesquisa teve por objetivo analisar o grau de esforço e a frequência de mobilização de competências docentes pela percepção dos 
professores de graduação em Ciências Contábeis no Rio Grande do Sul. Os resultados da pesquisa indicam que competências como pedagógica e tecnológica ainda são consideradas menos desenvolvidas entre os docentes, ao contrário das competências técnica, de comunicação, didática e reflexiva, as quais são consideradas mais desenvolvidas entre os docentes, corroborando achados de Nossa (1999), Laffin (2005), Andere e Araújo (2008), Slomski, et al. (2013), Marshall et al. (2010), Miranda et al. (2012), Vendruscolo e Behar (2014), Vendruscolo (2017) e Lima e Araújo (2020).

A análise revela docentes que intermediam o processo de ensino e aprendizagem, que apresentam domínio técnico e que possuem facilidade de comunicar o conteúdo específico; em contrapartida, apresenta docentes com dificuldades para dominar, repensar e aplicar na prática conhecimentos de tecnologia da informação e das teorias de ensino e aprendizagem. Adicionalmente, quanto maior o tempo de docência, tanto mais facilmente o professor de Ciências Contábeis concebe as atividades de ensino, utiliza conhecimentos técnicos e tecnológicos, além de, mais frequentemente, estar disposto a moldar sua forma de comunicação, a buscar aprimoramento técnico e didático e a trabalhar questões relacionadas com o processo e atividades de ensino.

Os achados da pesquisa indicam que as competências mais frequentemente demandadas pelos docentes são também aquelas que requerem maiores esforços para sua mobilização. A análise da percepção do esforço revelou que, em média, 65\% dos docentes apresentaram dificuldades em grau moderado ou alto de mobilização de suas de competências docentes. As competências pedagógica e didática foram consideradas com alto grau de esforço de mobilização, da mesma forma que as competências reflexivas e tecnológicas.

Por outro lado, os docentes julgaram ter mais facilidades no âmbito das competências técnica (três questões de quatro), de comunicação (três questões de cinco), de reflexão (uma de três) e tecnológica (uma de quatro). Embora haja maior frequência de mobilização das competências pedagógica e tecnológica, há um esforço maior na operacionalização das competências didáticas, de comunicação e técnica, resultados esses capazes de sugerir que, apesar da busca pelo aprimoramento e desenvolvimento das competências docentes no lapso dos últimos 20 anos, os problemas relacionados às competências docentes persistem atuais e necessitam de aprimoramentos.

As análises demonstraram que, em média, os docentes que cursaram a disciplina de metodologia do Ensino Superior na pós-graduação julgaram apresentar mais facilidade para aplicar as teorias de aprendizagem e os conhecimentos de tecnologia da informação e para pensar criticamente sobre elas e aplicá-las na prática docente do que aqueles docentes que não cursaram a disciplina. Entretanto, apresentaram mais facilidades para lidar com questões relacionadas ao saber ser professor e mediar o processo de ensino e aprendizagem aqueles docentes que não cursaram a disciplina de metodologia do Ensino Superior na pós-graduação e que não participaram de capacitação técnica. Tais resultados podem estar associados ao desenvolvimento de competências docentes pela reflexão dos professores sobre a sua prática docente, como sugerem Marshall et al. (2010), Lapini (2012), Engel et al. (2015), Miranda et al. (2017) e Araújo et al. (2021), assim como, que o aprimoramento da formação em nível stricto sensu contribui com a formação mais crítica do professor. Os achados também suscitam questionamentos adicionais sobre os

\footnotetext{
148 Revista Contabilidade Vista \& Revista, ISSN 0103-734X, Universidade Federal de Minas Gerais,
} Belo Horizonte, v. 32, n. 3, p. 123-164, set./dez. 2021 
processos cognitivos envolvendo o desenvolvimento de competências docentes e a mobilização e a articulação de conhecimentos, habilidades e atitudes para a resolução das situações oriundas no processo de ensino e aprendizagem, tal qual destacado por Vendruscolo (2015).

Conforme verificado em estudos anteriores e confirmado pelos resultados desta pesquisa, a formação dos docentes é voltada para a construção de conhecimentos teóricos e específicos da área contábil, enquanto à formação didático-pedagógica estaria sendo relegada a um plano menor. Os estudos apontam, e a pesquisa ratifica, a relevância dos esforços individuais para desenvolvimento das competências docentes e um maior comprometimento com a educação continuada, especialmente no que tange ao desenvolvimento das competências didática e pedagógica, bem como em relação às competências reflexiva e tecnológica.

Apesar de parte dos docentes ter recebido algum tipo de formação considerada pedagógica, a quantidade de professores que cursaram disciplinas de metodologia do Ensino Superior e o contingente de docentes que buscou esse tipo de aprimoramento em programas oferecidos pela instituição ou em cursos nos leva a questionar a formação de mestres e doutores em Contabilidade no país. A falta de preparação específica para o exercício da docência associada às dificuldades de cunho didático-pedagógico, reflexivo e tecnológico conduz ao debate e aprofundamento de estudos em programas de pós-graduação nessa temática capazes de resultarem em efetivas melhorias à formação docente.

Tais resultados, a partir da percepção dos professores, evidenciam a necessidade de se repensar a formação para a docência na área contábil. Estudar as práticas de ensino e a formação docente num contexto de intensas mudanças sociais e num contexto de incipiência, enquanto linha de pesquisa em Ciências Contábeis, é um desafio essencial para aprimoramento do processo de ensino e aprendizagem. Diante disso, urge trazer à tona discussões a respeito dos assuntos que permeiam esse processo, bem como a busca de alternativas de melhoria em cada espaço formativo docente.

Sugere-se, a partir dos resultados da pesquisa, no âmbito das IES e de órgãos reguladores da profissão contábil, o incentivo e a sistematização de programas mais efetivos de educação continuada que permitam aos professores momentos de reflexão sobre seu fazer pedagógico, contemplem embasamento teórico da aprendizagem e das metodologias de ensino em espaços de interação com outros professores, a exemplo de workshops, palestras, cursos, oficinas para auxiliá-los no processo formativo e na preparação para atuação em sala de aula, contribuindo com mudanças nas práticas desses docentes. No âmbito dos cursos de Pós-graduação, um aprimoramento da formação em nível stricto sensu seria capaz de contribuir com a formação crítica dos docentes, podendo ser instigado por meio de disciplinas como estágio docência e metodologia do ensino, programas de tutoria, incentivo à busca por uma formação didático-pedagógica e conscientização da necessidade de esforços individuais para sua efetivação. No âmbito dos órgãos de representação profissional seriam relevantes iniciativas no sentido de propiciar a formação de grupos de pesquisas que possam trazer à baila discussões a respeito da realidade enfrentada nas salas de aula, submetendo-as à reflexão coletiva por meio de 
fóruns, espaços para se conversar sobre a docência, para discussão e para troca de ideias entre professores na forma de eventos.

Em síntese, a pesquisa apresentou, de forma pioneira, aspectos demográficos dos docentes do Ensino Superior de Graduação em Ciências Contábeis no Rio Grande do Sul, contribuindo com dados empíricos da área do ensino contábil colaborando para o desenvolvimento da pesquisa acerca da formação para a docência e possibilitando a identificação de necessidades de capacitação, contribuindo para a melhoria da formação do professor de Contabilidade e a agregação de valor àquilo que é efetivamente entregue aos alunos como resultado da aplicação das competências docentes. O estudo também contribui com os estudantes de Ciências Contábeis ao evidenciar o esforço dos seus docentes em desenvolverem suas competências docentes. A pesquisa fornece subsídios para os órgãos de classe da área contábil implementarem programas sistemáticos de educação continuada que contemplem as necessidades pedagógicas dos professores dos cursos de graduação em Contabilidade. Tais contribuições apresentam atributos teóricos e práticos para responder anseios da sociedade e a busca contínua pela melhoria do ensino superior brasileiro, e de forma mais específica, para as Ciências Contábeis.

Por limitações da pesquisa, quanto ao público-alvo, tem-se o fato de haverem sido desconsiderados outros agentes que fazem parte do processo de ensino levando em conta apenas a perspectiva dos docentes e o fato de o levantamento dos dados ter ocorrido apenas no âmbito do estado do Rio Grande do Sul. Tendo em vista não ter sido possível conhecer o número de docentes existentes na região pesquisada, recorreu-se à amostragem não probabilística; todavia, esse tipo de amostragem não permite identificar a probabilidade que um elemento tem de pertencer à amostra, razão pela qual os resultados da pesquisa não podem ser estatisticamente generalizados para toda a população. Outro ponto considerado limitativo e indicativo de algum tipo de viés para a pesquisa é o fato de a análise pautar-se na percepção dos docentes, o que, pode estar relacionada a um certo grau de subjetividade do respondente, além das características individuais de cada um.

Sugere-se, para pesquisas futuras, a ampliação do estudo para âmbito nacional, a investigação, em profundidade, das competências pedagógica e tecnológica no âmbito da prática docente, ainda consideradas menos desenvolvidas entre os docentes e a proposição de uma análise comparativa do desempenho de discentes cuja formação se deu por docentes com e por docentes sem qualificação pedagógica.

\section{REFERÊNCIAS}

Alves, F. S. L, \& D'Souza, M. F. (2018). Formação didático-pedagógica: análise das competências docentes no curso de Ciências Contábeis. Anais do Congresso USP de Iniciação Científica em Contabilidade, São Paulo, SP, Brasil, 15.

Andere, M. A., \& Araújo, A. M. P. (2008). Aspectos da formação do professor de ensino superior de Ciências Contábeis: uma análise dos programas de pósgraduação. Revista de Contabilidade e Finanças, 19(48), 91-102. https://doi.org/10.1590/S1519-70772008000300008 
Araujo, A. M. P. de. (2017). Formação do professor de Contabilidade: uma proposta pedagógica. Revista de Estudios e Investigación en Psicología y Educación, 6, 49-54. https://doi.org/10.17979/reipe.2017.0.06.2222

Araujo, A. M. P. de, \& Mello, R. R. de. (2014). What Is the training of the Accounting professor in Brazil?. Creative Education, 5, 886-899. http://dx.doi.org/10.4236/ce.2014.511102

Araújo, T. S., Leal, E. A., \& Lourenço, R. F. (2021). Expectativas e satisfação dos discentes sobre os saberes e competências requeridas dos docentes na área de Ciências Contábeis. Revista Ambiente Contábil - UFRN, 13(1), 324-342. https://doi.org/10.21680/2176-9036.2021v13n1ID20179

Araújo, T. S., Lima, F. D. C., Oliveira, A. C. L., \& Miranda, G. J. (2015). Problemas percebidos no exercício da docência em Contabilidade. Revista Contabilidade e Finanças, 26(67), 93-105. https://doi.org/10.1590/1808$\underline{057 \times 201512230}$

Araújo, T. S., Miranda, G. J., \& Pereira, J. M. (2017). Satisfação dos professores de Contabilidade no Brasil. Revista Contabilidade \& Finanças, 28(74), 264-281. https://doi.org/10.1590/1808-057×201703420

Barbosa, R. S., Leal, E. A., \& Nganga, C. S. N. (2019). Estratégias de ensino aplicadas na pós-graduação em Contabilidade. Revista Educação e Cultura Contemporânea, 16(45), 548-574. http://dx.doi.org/10.5935/2238$\underline{1279.20190094}$

Bolzan, G., Vendruscolo, M. I., Sallaberry, J. D., \& Diehl, W. (2020). O ensino de Ciências Contábeis e o processo de convergência ao International Financial Reporting Standards. Revista Ambiente Contábil, 12(1). 130-151. https://doi.org/10.21680/2176-9036.2020v12n11D18313

Colauto, R. D., \& Beuren, I. M. (2018). Coleta análise e interpretação dos dados. In: Beuren, I. M. (org.) Como elaborar trabalhos monográficos em Contabilidade. São Paulo: Atlas. pp. 117-144

Costa, S. R. S., Duqueviz, B. C., \& Pedroza, R. L. S. (2015). Tecnologias digitais como instrumentos mediadores da aprendizagem dos nativos digitais. Revista Quadrimestral da Associação Brasileira de Psicologia Escolar e Educacional, 19(3), 603-610. https://doi.org/10.1590/2175-3539/2015/0193912

Del Mundo, G. V., \& Refozar, R. F. G. (2013). The accounting teachers of Batangas: their profiles competencies and problems. International Scientific Research Journal, 5(1), 131-166.

Engel, C. I., Vendruscolo, M. I., \& Bianchi, M. (2015). Formação docente do curso de Ciências Contábeis: um estudo da base pedagógica nos programas stricto sensu. Anais do Congresso UFSC de Controladoria e Finanças, 
Florianópolis, Brasil, 6.

Farias, R. S. (2016). Percepção dos professores de contabilidade no Brasil no tocante a competências didático-pedagógicas para o exercício da docência. (Dissertação de Mestrado), Universidade de São Paulo, Ribeirão Preto, SP, Brasil.

Farias, R. S. de, \& Araujo, A. M. P. de. (2018). Teacher professional development: field of knowledge rise. Creative Education, 9, 658-674. DOl: $10.4236 /$ ce 2018.95048

Farias, R. S. de, \& Araújo, A. M. P. de. (2016). Percepção dos professores de contabilidade quanto aos espaços formativos para o ofício da docência no Brasil. Revista de Contabilidade e Organizações, 10(28), 58-70. https://doi.org/10.11606/rco.v10i28.124789

Farias, R. S., Stanzani, L. M. L., Lima, J. P. R., \& Araujo, A. M. P. de. (2020). Preparação para a docência universitária: um estudo dos espaços formativos. BASE Revista de Administração e Contabilidade da Unisinos, 17(4), 606-633. https://doi.org/10.4013/base.2020.174.04

Field, A. (2009). Descobrindo a estatística usando o SPSS. (2a ed.). Porto Alegre: Artmed.

Frauches, P. F. (2015). Docência no ensino superior: um perfil dos saberes que fundamentam a prática pedagógica de docentes que atuam em cursos de Ciências Contábeis. (Dissertação de Mestrado), Fundação Escola de Comércio Álvares Penteado, São Paulo, SP, Brasil.

Giorgi, W. A. B. D., Pizolato, C. L., \& Morettin, A. A. (2001). Competências e habilidades e o ensino superior de Contabilidade. Revista Pensar Contábil, 4(16), 9-12.

Gujarati, D. (2006). Econometria Básica. (4a ed.). Rio de Janeiro: Campus.

Hair, J. F., Black, W. C., Babin, B. J., Anderson, R. E., \& Tatham, R. L. (2019). Análise multivariada de dados. (6a ed.). Porto Alegre: Bookman.

Hillen, C., Laffin, M., \& Ensslin, S. R. (2018). Proposições sobre formação de professores na área contábil. Arquivos Analíticos de Políticas Educativas, 26(106). http://dx.doi.org/10.14507/epad.26.3060

Huberman, M. (2000). O ciclo de vida professional de professores. In: Nóvoa, A. (org) Vida de professores. Porto Editora.

Laffin, M. (2005). De contador a professor: a trajetória da docência no ensino superior da Contabilidade. Florianópolis: Imprensa Universitária.

Lapini, V. C. (2012). Panorama da formação do professor em Ciências Contábeis pelos cursos strictu sensu no Brasil. (Dissertação de Mestrado), Universidade de 
São Paulo, Ribeirão Preto, SP, Brasil.

Libâneo, J.C. (2008). Organização e gestão da escola: teoria e prática. (5a ed.). Goiânia: MF Livros.

Likert, R. (1975). A organização humana. São Paulo: Atlas.

Lima, F. D. C., Oliveira, A. C. L., Araújo, T. S., \& Miranda, G. J. (2015). O choque com a realidade: dormi contador e acordei professor... Revista Iberoamericana sobre Calidad, Eficacia y Cambio en Educación, 13(1), 49-67.

Lima, J. P. R. de, \& Araujo, A. M. P. de. (2019). Tornando-se professor: análise do processo de construção da identidade docente dos professores de contabilidade. Advances in Scientific and Applied Accounting, 1(2), 59-80. https://doi.org/10.14392/ASAA.2019120204

Marshall, P. D., Dombrowski, R., Garner, M., \& Smith, K. (2010). The Accounting education gap. The CPA Journal, 80(6), 6-10.

Marshall, P. D., Smith, K., Dombrowski, R., \& Garner, M. (2012). Accounting faculty perceptions of the influence of educational and work experiences on their performance as educators. The Accounting Educators Journal, 22, 73-91.

Masetto, M. T. (2012). Competência pedagógica do professor universitário. (2a ed.). São Paulo: Summus.

Miranda, G. J. (2010). Docência universitária: uma análise das disciplinas na área da formação pedagógica oferecidas pelos programas de pós-graduação stricto sensu em Ciências Contábeis. Revista de Educação e Pesquisa em Contabilidade, 4(2), 81-98.

Miranda, G. J., Casa Nova S. P. C., \& Cornacchione, J. E. B. (2012). Os Saberes dos professores-referência no ensino de Contabilidade. Revista Contabilidade \& Finanças, 23(59), 142-153. https://doi.org/10.1590/S1519-70772012000200006

Miranda, G. J., Santos, L. A. A., Casa Nova, S. P. C., \& Cornacchione Júnior, E. B. (2013). A Pesquisa em educação contábil: produção científica e preferências de doutores no período de 2005 a 2009. Revista Contabilidade \& Finanças, 24(61), 75-88. https://doi.org/10.1590/S1519-70772013000100008

Miranda, G. J., Carrazana, X. E. V, Pereira, J. M., Araujo, T. S., \& Silva, T. L. G. B. (2017). Relación entre los problemas del proceso de enseñanza-aprendizaje de la carrera de Contabilidad y las fases del ciclo de vida de los docentes. Ensino Em Re-Vista, 24(2), 408-430. http://dx.doi.org/10.14393ER-v24n2a2017-06

Nganga, C. S. N., Botinha, R. A., Miranda, G. J., \& Leal, E. A. (2016). Mestres e doutores em Contabilidade no Brasil: uma análise dos componentes pedagógicos de sua formação inicial. Revista lberoamericana sobre Calidad, Eficacia y Cambio en Educación, 14(1), 83-99. 10.15366/reice2016.14.1.005 
Nossa, V. (1999). O ensino da Contabilidade no Brasil: uma análise crítica da formação do corpo docente. (Dissertação de Mestrado). Universidade de São Paulo, São Paulo, SP Brasil.

Perazo, A. N. C., Machado, D. G., Cruz, A. P. C., \& Quintana, A. C. (2016). Perfil do docente de Ciências Contábeis: perspectiva de sua qualificação acadêmica, pedagógica e profissional. Revista de Contabilidade e Controladoria, 8(2), 49-65. https://doi.org/10.5380/rcc.v8i2.38481

Pereira, M. A. C. (2007). Competências para o ensino e a pesquisa: um survey com docentes de engenharia química. (Tese de Doutorado), Universidade de São Paulo, São Paulo, SP Brasil.

Silva, C. F., Ferreira, L. V., Leal, E. A., \& Miranda, G. J. (2019). Formação docente na área contábil: contribuições da disciplina de metodologia do ensino oferecida na pós-graduação stricto sensu. Sociedade, Contabilidade e Gestão, 14(3). https://doi.org/10.21446/scg ufrj.v0i0.23062

Silva, U. B. da, \& Bruni, A. L. (2017). O Que me ensina a ensinar? Um estudo sobre fatores explicativos das práticas pedagógicas no ensino de Contabilidade. Revista de Educação e Pesquisa em Contabilidade (REPeC), 11(2). https://doi.org/10.17524/repec.v11ii2.1531

Slomski, V. G. (2007). Saberes e competências do professor universitário: contribuições para o estudo da prática pedagógica do professor de Ciências Contábeis do Brasil. Revista de Contabilidade e Organizações, 1(1), 89-105. https://doi.org/10.11606/rco.v1i1.34699

Slomski, V. G. (2009). Saberes que fundamentam a prática pedagógica dos professores de Ciências Contábeis. Revista Brasileira de Contabilidade, 39(180), 119-140.

Slomski, V.G., Anastácio, J.B., Araujo, A. M. P. de, Slomski, V., \& Carvalho, R.F. (2020). Casos da prática educativa na aprendizagem da docência universitária. Arquivos Analíticos de Políticas Educativas, 28(33). https://doi.org/10.14507/epaa.28.5041

Slomski, V. G., \& Martins, G. A. (2008). O conceito de professor investigador: os saberes e as competências necessárias à docência reflexiva na área contábil. Revista Universo Contábil, 4(4), 06-21.

Slomski, V. G., Lames, E. R., Megliorini, E., \& Lames, L. C. J. (2013). Saberes da docência que fundamentam a prática pedagógica do professor que ministra a disciplina de gestão de custos em um curso de Ciências Contábeis. Revista Universo Contábil, 9(4), 71-89. https://doi.org/10.4270/ruc.2013431

Swain, M. R., \& Stout, D. E. (2000). Survey evidence of teacher development based on AECC recommendations. Journal of Accounting Education, 18(2), 99-1 13. https://doi.org/10.1016/S0748-5751(00)00013-0 
Tardif, M., \& Raymond, D. (2000). Saberes, tempo e aprendizagem do trabalho no magistério. Educação \& Sociedade, 21(73), 209-244. https://doi.org/10.1590/s0101-73302000000400013

Vasconcelos, A. F. (2009). Professores em Ciências Contábeis: um estudo sobre as competências para o exercício da docência nos cursos presenciais no Nordeste brasileiro. (Dissertação de Mestrado), Universidade Federal da Paraíba e Universidade Federal do Rio Grande do Norte, João Pessoa, PB, Brasil.

Vasconcelos, A. F., Cavalcante, P. R. N., \& Monte, P. A. (2012). Fatores que influenciam as competências em docentes de Ciências Contábeis. VEREDAS FA VIP - Revista eletrônica de Ciências, 5(1), 86-101.

Vendruscolo, M. I. (2015). Modelo pedagógico para o desenvolvimento de competências docentes em Contabilidade por educação a distância. (Tese de Doutorado), Universidade Federal do Rio Grande do Sul, Porto Alegre, RS, Brasil.

Vendruscolo, M. I. (2017). Competências docentes: um estudo empírico com professores de cursos de graduação em Ciências Contábeis no Brasil. Anais do Congresso ANPCONT, Belo Horizonte, MG, Brasil, 10.

Vendruscolo, M. I., \& Behar, P. A. (2014). Educação e pesquisa em Contabilidade: estado da arte do Congresso USP de Controladoria e Contabilidade do período de 2004 a 2012. Ambiente Contábil, 6(1), 83-98.

Verdum, P. (2013). Prática Pedagógica: o que é? O que envolve? Revista Educação por Escrito, 4(1), 91-105.

Zanella, P., Antonelli, R. A., \& Bortoluzzi, S. C. (2017). Avaliação das competências docentes: análise no curso de Ciências Contábeis da UTFPR. Revista de Educação e Pesquisa em Contabilidade (REPeC), 11(2). https://doi.org/10.17524/repec.v11i2.1417 


\section{APÊNDICE: QUESTIONÁRIO}

Título: Esforço percebido pelos professores de graduação em Ciências Contábeis no Rio Grande do Sul para operacionalizar competências docentes

Pesquisadora responsável: Giovana Bolzan

Objetivo da pesquisa: analisar o esforço percebido pelos professores de graduação em Ciências Contábeis no Rio Grande do Sul para operacionalização das competências docentes.

\section{Autorização para Divulgação, Publicação e Cessão de Direitos Autorais:}

Ao responder esse Questionário, declaro que participo voluntariamente da pesquisa "Práticas docentes dos professores de graduação em Ciências Contábeis no Rio Grande do Sul", bem como cedo todos os direitos autorais, desde que os dados pessoais sejam mantidos em sigilo.

() Aceito

\section{PARTE I - INFORMACÕES RELATIVAS AO DOCENTE}

Indique o grau de concordância com a afirmação:

Considerando a minha formação para a docência, EU ESTOU PREPARADO(A) PARA O EXERCÍCIO DO MAGISTÉRIO SUPERIOR EM CIÊNCIAS CONTÁBEIS. *
() Discordo totalmente
() Discordo em parte
() Nem discordo nem concordo
( ) Concordo em parte
( ) Concordo totalmente

Considerando suas práticas em sala de aula, expresse:

na primeira linha, a frequência com que você realiza a tarefa descrita, utilizando a escala: (1) para nunca e (5) para sempre e, na segunda linha, a sua percepção em relação ao esforço necessário para a realização dessa tarefa, utilizando a escala: (1) para fácil e (5) para difícil.

\section{Planejo e organizo as atividades de ensino a partir de como penso que 0 conhecimento acontece \\ 1.1 Frequência \\ () nunca () raramente \\ 1.2 Percepção do esforço \\ () algumas vezes ( ) muitas vezes ( ) sempre \\ () muito fácil () fácil () nem fácil, nem difícil () difícil () muito difícil}

2. Concebo as atividades de ensino considerando as teorias de aprendizagem sob a perspectiva pedagógica

2.1 Frequência

() nunca () raramente () algumas vezes () muitas vezes () sempre

2.2 Percepção do esforço

( ) muito fácil () fácil ( ) nem fácil, nem difícil () difícil ( ) muito difícil 
3. Preparo material didático de apoio às atividades do curso com a utilização das tecnologias da informação e comunicação (TIC)

3.1 Frequência
() nunca () raramente
() algumas vezes
() muitas vezes
() sempre
3.2 Percepção do esforço
() muito fácil (
( ) fácil
( ) nem fácil, nem difícil (
() difícil
() muito difícil

4. Acompanho mudanças que envolvem os conhecimentos técnicos das disciplinas que ministro

4.1 Frequência
() nunca () raramente
() algumas vezes () muitas vezes
() sempre
4.2 Percepção do esforço
() muito fácil
( ) fácil
( ) nem fácil, nem difícil (
() difícil
() muito difícil

5. Exploro novos ambientes tecnológicos de aprendizagem

5.1 Frequência
() nunca () raramente
() algumas vezes () muitas vezes
() sempre

5.2 Percepção do esforço
() muito fácil
() fácil
() nem fácil, nem difícil
() difícil
() muito difícil

6. Aplico os conteúdos da(s) disciplina(s) que ministro com suficiente domínio técnico

6.1 Frequência
() nunca () raramente
() algumas vezes
() muitas vezes
() sempre
6.2 Percepção do esforço
( ) muito fácil
() fácil
( ) nem fácil, nem difícil
() difícil
( ) muito difícil

7. Relaciono os conteúdos ministrados em aula com os de outras disciplinas do curso e/ou outras áreas do saber

7.1 Frequência
() nunca () raramente
() algumas vezes
() muitas vezes
() sempre
7.2 Percepção do esforço
() muito fácil (1
() fácil
( ) nem fácil, nem difícil (
() difícil
() muito difícil

8. Relaciono os conteúdos ministrados em aula com conhecimentos construídos na prática docente e na prática profissional

8.1 Frequência
() nunca () raramente
() algumas vezes
() muitas vezes
( ) sempre
8.2 Percepção do esforço
() muito fácil
( ) fácil
( ) nem fácil, nem difícil
() difícil
() muito difícil

9. Reflito com os alunos sobre os conteúdos ministrados em sala de aula e sobre aspectos globais da ciência e da sociedade

9.1 Frequência
() nunca () raramente
() algumas vezes
() muitas vezes
() sempre
9.2 Percepção do esforço
() muito fácil
( ) fácil
( ) nem fácil, nem difícil
() difícil
( ) muito difícil 
10. Informo e envolvo os alunos em minhas aulas

10.1 Frequência
() nunca () raramente
( ) algumas vezes
() muitas vezes
( ) sempre
10.2 Percepção do esforço
( ) muito fácil
( ) fácil
( ) nem fácil, nem difícil
( ) difícil
( ) muito difícil

11. Comunico-me com clareza e objetividade, fazendo-me entender facilmente 11.1 Frequência
() nunca () raramente
() algumas vezes
() muitas vezes
() sempre
11.2 Percepção do esforço
( ) muito fácil
( ) fácil
( ) nem fácil, nem difícil
( ) difícil
( ) muito difícil

12. Utilizo diferentes estratégias de comunicação nas aulas (diálogo, conversação, interlocução, escrita)

12.1 Frequência
() nunca () raramente
12.2 Percepção do esforço
( ) algumas vezes
( ) muitas vezes
( ) sempre

() muito fácil

( ) fácil

( ) nem fácil, nem difícil

( ) difícil

( ) muito difícil

\section{Dou suporte aos alunos em tarefas cognitivas}

13.1 Frequência
() nunca () raramente
13.2 Percepção do esforço
() algumas vezes
() muitas vezes
( ) sempre
( ) muito fácil
( ) fácil
( ) nem fácil, nem difícil
( ) difícil
( ) muito difícil

\section{Apresento prontidão para atender às demandas dos alunos}

14.1 Frequência
() nunca () raramente
14.2 Percepção do esforço
() algumas vezes ( ) muitas vezes
( ) sempre
() muito fácil
( ) fácil
( ) nem fácil, nem difícil
( ) difícil
( ) muito difícil

\section{Incentivo o pensamento crítico dos alunos}

15.1 Frequência
() nunca () raramente
15.2 Percepção do esforço
() algumas vezes
( ) muitas vezes
( ) sempre
( ) muito fácil
( ) fácil
( ) nem fácil, nem difícil
( ) difícil
( ) muito difícil

16. Incentivo e desafio os alunos à busca de novos conhecimentos

16.1 Frequência
() nunca () raramente
16.2 Percepção do esforço
() algumas vezes () muitas vezes
( ) sempre
( ) muito fácil
( ) fácil
( ) nem fácil, nem difícil
( ) difícil
( ) muito difícil

\section{Exercito a mediação pedagógica e assessoro os alunos}

17.1 Frequência
() nunca () raramente
() algumas vezes
( ) muitas vezes
( ) sempre
17.2 Percepção do esforço
( ) muito fácil
( ) fácil
( ) nem fácil, nem difícil
( ) difícil
( ) muito difícil 
18. Aplico, em sala de aula, conhecimentos das teorias de ensino e aprendizagem

18.1 Frequência
() nunca () raramente
() algumas vezes () muitas vezes
() sempre
18.2 Percepção do esforço
() muito fácil (1
( ) fácil
( ) nem fácil, nem difícil
() difícil
( ) muito difícil

\section{Aplico novas tecnologias no processo de ensino e aprendizagem}

19.1 Frequência
() nunca () raramente
19.2 Percepção do esforço
() algumas vezes () muitas vezes
() sempre
() muito fácil (1)
( ) fácil
( ) nem fácil, nem difícil
() difícil
() muito difícil

\section{Mantenho-me tecnologicamente atualizado}

20.1 Frequência
() nunca () raramente
() algumas vezes
() muitas vezes
() sempre
20.2 Percepção do esforço
() muito fácil
( ) fácil
( ) nem fácil, nem difícil (
( ) difícil
() muito difícil

21. Reflito a respeito de minha prática docente antes, durante ou depois da ação 21.1 Frequência
() nunca () raramente
21.2 Percepção do esforço
() algumas vezes () muitas vezes
() sempre
() muito fácil
( ) fácil
( ) nem fácil, nem difícil (
() difícil
() muito difícil

\section{Promovo melhorias no processo de ensino-aprendizagem}

22.1 Frequência
() nunca () raramente
22.2 Percepção do esforço
() algumas vezes () muitas vezes
() sempre
( ) muito fácil
( ) fácil
( ) nem fácil, nem difícil
() difícil
() muito difícil

\section{PARTE II - INFORMACÕES RELATIVAS AO DOCENTE}

Tempo de carreira docente em anos (indicar o número inteiro):

Em relação à formação para a docência no Ensino Superior, indique as opções que você já cursou: (pode haver mais de uma resposta) * (Marque todas que se aplicam)

( ) disciplina de metodologia do Ensino Superior na pós-graduação

( ) estágio supervisionado na área de educação superior

( ) programa de preparação para a docência oferecido pela Instituição de

Ensino Superior que trabalha

( ) cursos de capacitação técnica

( ) cursos de capacitação didático-pedagógica

( ) cursos de capacitação educacional (contexto do Ensino Superior)

( ) curso de pós-graduação lato sensu na área da Educação

( ) curso de pós-graduação stricto sensu na área da Educação

() não frequentou cursos na área da formação para a docência universitária

() Outro: 
Você acredita que suas competências pedagógicas foram desenvolvidas: (pode haver mais de uma resposta) * (Marque todas que se aplicam)

( ) na formação básica

( ) em programas de pós-graduação lato sensu

( ) em programas de pós-graduação stricto sensu

( ) nas instituições de ensino onde atua/atuou

() a partir de esforços individuais de capacitação docente

( ) não acredita que são necessários cursos formativos específicos para o exercício da docência

Com que frequência, você, nos últimos dois anos, ... (Marcar apenas uma oval por linha)

participou de eventos científicos (congressos, seminários, simpósios, etc) DA ÁREA OU DE ÁREAS AFINS

() nunca () raramente (1) algumas vezes () muitas vezes (1) sempre participou de eventos científicos (congressos, seminários, simpósios, etc) DA ÁREA EDUCACIONAL

() nunca () raramente () algumas vezes () muitas vezes () sempre desenvolveu projetos de pesquisa
() nunca
() raramente
() algumas vezes () muitas vezes
( ) sempre

participou de cursos de aperfeiçoamento técnico

() nunca (1) raramente () algumas vezes ( ) muitas vezes participou de cursos de preparação para a docência
() nunca
() raramente
() algumas vezes () muitas vezes
() sempre

() sempre

participou de eventos na área pedagógica
() nunca
() raramente
() algumas vezes ( ) muitas vezes
( ) sempre

teve artigos publicados em eventos científicos ou periódicos
() nunca
() raramente
() algumas vezes () muitas vezes
( ) sempre

teve livro(s) de sua autoria publicado
() nunca
() raramente
() algumas vezes (1) muitas vezes
( ) sempre promoveu sua formação pedagógica continuada
() nunca
() raramente
() algumas vezes (1) muitas vezes promoveu sua formação reflexiva continuada (desenvolvimento de atitudes e competências problematizadoras das práticas de ensino)
() nunca
() raramente
( ) algumas vezes
( ) muitas vezes
( ) sempre

Com que frequência a Instituição de Ensino Superior que você trabalha atualmente ... (Marcar apenas uma oval por linha)

apoia a participação dos docentes em projetos de pesquisa
() nunca
() raramente
() algumas vezes (1) muitas vezes
( ) sempre apoia a participação dos professores em eventos científicos
() nunca () raramente
() algumas vezes () muitas vezes
( ) sempre oferta programas de preparação para a docência
() nunca () raramente
() algumas vezes () muitas vezes apoia a participação em programas de preparação para a docência
() nunca
( ) raramente
( ) algumas vezes
( ) muitas vezes
( ) sempre
( ) sempre 
propõe atividades que possibilitam o aprimoramento e a capacitação pedagógica do docente
() nunca
() raramente
() algumas vezes () muitas vezes
() sempre incentiva financeiramente $o$ aprimoramento acadêmico ou a participação do docente em eventos
() nunca
( ) raramente
() algumas vezes
() muitas vezes
() sempre

Área das disciplinas ministradas na graduação NO Curso de Ciências Contábeis (pode haver mais de uma resposta) * (Marque todas que se aplicam)
() ministro disciplinas somente em Outros Cursos
( ) ministro disciplinas somente em cursos de pós-graduação
() não ministro disciplinas
( ) Sou Coordenador(a) do curso de Ciências Contábeis
() de Introdução a Contabilidade
() de Contabilidade Intermediária
() de Contabilidade Avançada ou de Tópicos Avançados de Contabilidade
( ) de Estrutura e ou Análise das Demonstrações Contábeis
() de Custos
() de Finanças
() de Auditoria e Perícia
() de Governamental ou Contabilidade Pública
() de Outras da Área Contábil
() de Outras de Áreas Afins

Número médio de disciplinas ministradas por semestre (graduação e pósgraduação - considere os últimos dois anos) *
modalidade presencial: ( )
() 1 (1) 2 (1) 3
() 4
() 5 () mais de 5
modalidade de ensino a distância: ( ) 0
() 1 (1) 2
() 3
() 4 (1) 5
mais de 5

Qual sua carga horária de trabalho semanal como docente no Ensino Superior? (graduação e pós-graduação)
() menos de 12 horas
() mais de 12 horas e menos de 20 horas
() entre 21 horas e 32 horas
() entre 33 horas e 40 horas
( ) dedicação exclusiva à docência

Número médio de alunos por turma (considere as turmas de graduação nos últimos dois anos)
() até 20 alunos
() de 20 a 30 alunos
() de 30 a 40 alunos
() de 40 a 50 alunos
() de 50 a 60 alunos
() de 60 a 70 alunos
() mais de 70 alunos 
A principal Instituição de Ensino Superior de atuação (pode haver mais de uma resposta)

( ) Instituição Pública

( ) Instituição Privada

Escolha as opções que representam a sua formação acadêmica $E$ a sua maior titulação - (ESPECIFICAR A ÁREA - pode haver mais de uma resposta por pergunta) * (Marque todas que se aplicam).

\section{Graduação}

() Em Ciências Contábeis

() Em áreas afins

( ) Em outras áreas do conhecimento

\section{Especialização}

( ) Não possuo

() Em andamento

( ) Em Ciências Contábeis

() Concluído

( ) Em áreas afins

( ) Em outras áreas do conhecimento

\section{Mestrado}
( ) Não possuo
() Em andamento
() Em Ciências Contábeis
( ) Concluído
() Em áreas afins
() Em outras áreas do conhecimento

\section{Doutorado}
() Não possuo
() Em andamento
() Concluído
() Em Ciências Contábeis
() Em áreas afins
() Em outras áreas do conhecimento

\section{Pós-Doutorado}
( ) Não possuo
() Em andamento
() Concluído
() Em Ciências Contábeis
() Em áreas afins
() Em outras áreas do conhecimento 
Considerando o mapa do RS abaixo, indique a região em que você atua. (caso possua dúvidas, verifique a região da cidade em: https://pt.wikipedia.org/wiki/Lista_de_mesorregi\%C3\%B5es_do_Rio_Grande_do_S ul) Marque todas que se aplicam.

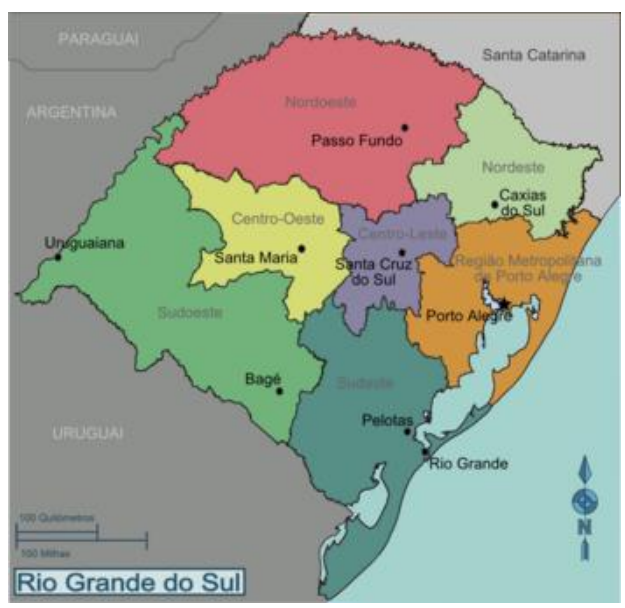

() Centro-leste

() Centro-oeste

() Nordeste

() Noroeste

() Região Metropolitana de Porto Alegre

() Sudeste

() Sudoeste

\section{Sua idade (em anos) *}

\section{Seu Gênero}

() Feminino

() Masculino

Espaço para seus comentários e contribuições (caso queira receber os resultados da pesquisa, deixe aqui seu e-mail). Obrigada pela sua participação! 


\section{CONTRIBUIÇÕES DOS AUTORES}

\begin{tabular}{|l|c|c|}
\hline \multicolumn{1}{|c|}{ Contribuição } & Giovana Bolzan & $\begin{array}{c}\text { Maria Ivanice } \\
\text { Vendruscolo }\end{array}$ \\
\hline $\begin{array}{l}\text { 1. Idealização e concepção do assunto e tema da } \\
\text { pesquisa }\end{array}$ & $\checkmark$ & \\
\hline 2. Definição do problema de pesquisa & $\checkmark$ & $\checkmark$ \\
\hline 3. Desenvolvimento da Plataforma Teórica & $\checkmark$ & \\
\hline $\begin{array}{l}\text { 4. Delineamento da abordagem metodológica da } \\
\text { pesquisa }\end{array}$ & $\checkmark$ & \\
\hline 5. Coleta de dados & $\checkmark$ & \\
\hline 6. Análises e interpretações dos dados coletados & $\checkmark$ & \\
\hline 7. Conclusões da pesquisa & $\checkmark$ & $\checkmark$ \\
\hline 8. Revisão crítica do manuscrito & $\checkmark$ & $\checkmark$ \\
\hline $\begin{array}{l}\text { 9. Redação final do manuscrito, conforme as normas } \\
\text { estabelecidas pela Revista. }\end{array}$ & & $\checkmark$ \\
\hline 10. Orientação & & \\
\hline
\end{tabular}

